
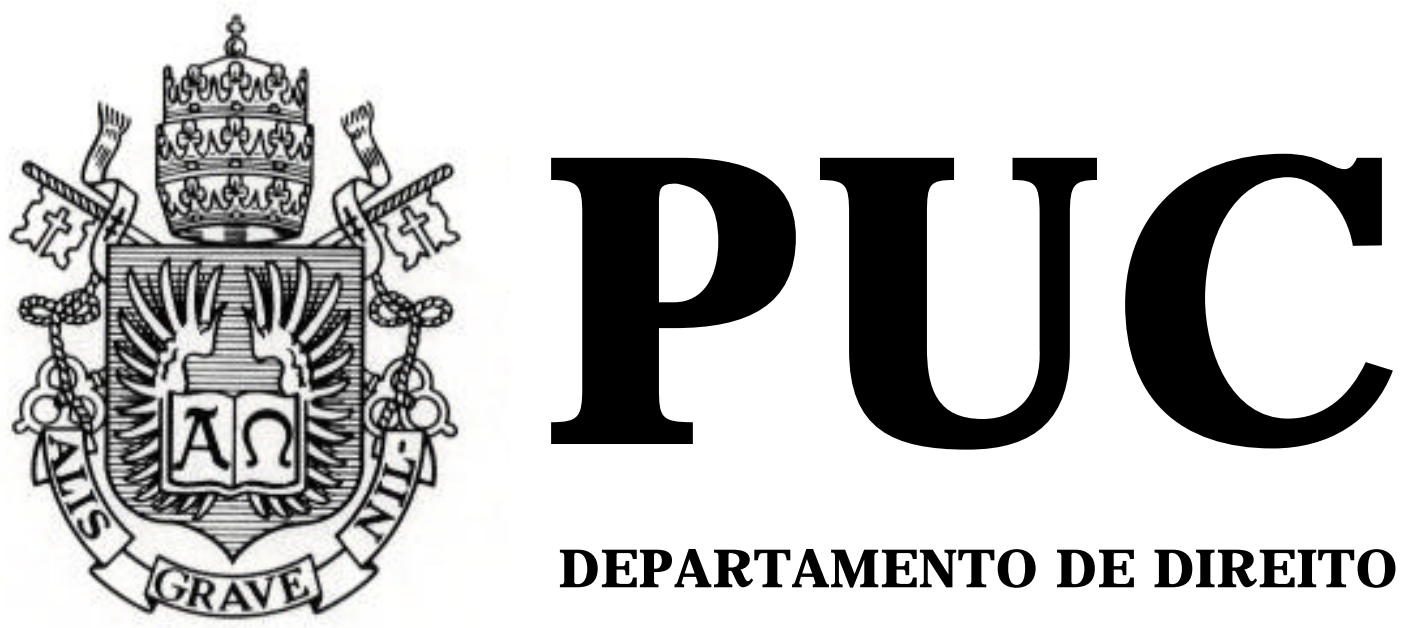

DEPARTAMENTO DE DIREITO

\title{
MANIPULAÇÃO DE MERCADO E OUTROS ILÍCITOS NO MERCADO DE VALORES MOBILIÁRIOS
}

por

PEDRO MASSENA

Orientador:

MARCELO FERNANDEZ TRINDADE

2008.2

PONTIFÍCIA UNIVERSIDADE CATÓLICA DO RIO DE JANEIRO

RUA MARQUÊS DE SÃO VICENTE, 225 - CEP 22451-900

RIO DE JANEIRO - BRASIL 


\title{
Manipulação de Mercado e outros ilicitos no Mercado de Valores Mobiliários
}

\author{
por \\ PEDRO MASSENA
}

Monografia

apresentada

ao

Departamento de Direito da Pontifícia

Universidade Católica do Rio de Janeiro (PUC-Rio) como requisito parcial para a obtenção do Título de Bacharel em Direito.

Orientador: Marcelo Fernandez Trindade 
A meu sobrinho, Miguel, que a cada dia renova minha esperança de viver um mundo melhor. 


\section{Agradecimentos}

À Juliana Argimon, pela inspiração e por todo o apoio que alguém poderia ter.

Aos meus pais, Mauricio e Fernanda, exemplos nos quais tento me espelhar a cada dia.

Aos meus amigos Caetano Altafin, Marcelo Queiroz, Bernardo Egas, Pedro Ivo Fajardo e tantos outros que não menciono para não dar ensejo a ainda maiores injustiças, pelo apoio, pelos bons momentos, pelas "falácias" rotineiras que tanto me motivaram.

Ao "professor", Nelson Eizirik, pelo apoio inestimável dado a este trabalho e pelo exemplo de profissional, de chefe, de pai, de ser humano, que contagia todos ao seu redor.

À PUC-Rio, por este ambiente que faz os que dela partem logo ansiarem o retorno. 


\section{Resumo}

MASSENA, Pedro. Manipulação de Mercado e outros ilícitos no Mercado de Valores Mobiliários. Rio de Janeiro, 59p. 2008. Monografia de final de curso Departamento de Direito, Pontifícia Universidade Católica do Rio de Janeiro.

$\mathrm{O}$ presente trabalho monográfico visa a tentar analisar e, posteriormente, sistematizar os ilícitos dispostos na Instrução CVM 08/1979, conforme competência definida pela Lei 6.385/1976. Apesar de tratar de todas as condutas antijurídicas definidas no ato normativo citado, o foco do trabalho é definir o ilícito de manipulação de mercado, e a partir daí conceituar os ilícitos de criação de condições artificiais de demanda, oferta e preço e de manipulação de preços, ambos também tipificados no texto normativo referido.

Para isso, a monografia inicia com a delimitação dos princípios que devem nortear a atividade do órgão regulador do mercado de valores mobiliários - a CVM. A partir daí, tenta-se extrair os requisitos para a caracterização dos ilícitos citados no parágrafo anterior, analisando a jurisprudência da autarquia, o Direito Penal e o Direito Comparado.

\section{Palavras-chave}

Direito Societário, Mercado de Capitais, Mercado de Valores Mobiliários, Princípios, Eficiência, Estabilidade, Credibilidade, Informação, Proteção ao Investidor, Infrações ao Mercado, Manipulação de Mercado, Condições Artificiais de Demanda, Oferta e Preço, Operações Fraudulentas, Manipulação de Preços, Prática não Eqüitativa, Comissão de Valores Mobiliários, Instrução CVM 08/1979. 


\section{Sumário}

\section{INTRODUÇÃO}

1.1. Colocação do Problema

1.2. Delimitação do Tema

1.3. Metodologia

2. CONDIÇÕES PARA UM FUNCIONAMENTO ADEQUADO DO MERCADO DE VALORES MOBILIÁRIOS

2.1. Noção de mercado perfeito, imperfeições e finalidade da regulação estatal

2.2. Princípios norteadores da atuação regulatória no âmbito do Mercado de

Valores Mobiliários

2.2.1. Eficiência

2.2.2. Informação

2.2.3. Proteção aos investidores

\section{ILÍCITOS NO MERCADO DE VALORES MOBILIÁRIOS}

3.1. Histórico e Caracterização na lei brasileira

3.2. Manipulação de Mercado no Direito Penal

3.3. Manipulação de Mercado no Direito Comparado

3.4. Infrações Previstas na Instrução 08/1979

3.5. Outros ilícitos previstos na Instrução CVM no 08/1979.

3.5.1. Operações Fraudulentas

3.5.2. Práticas não Eqüitativas

4. CONCLUSÃo 


\section{Capítulo 1 - Introdução}

\section{1 - Colocação da questão}

O presente trabalho monográfico visa a investigar os múltiplos aspectos que giram ao redor da aplicação, por parte da Comissão de Valores Mobiliários - CVM, autarquia criada pela Lei 6385, de 14 de dezembro de 1976 - da Instrução CVM nº 08/1979, que possui, como objetivo principal, definir e delimitar práticas tidas como maléficas ao Mercado de Capitais, quais sejam: (i) a criação de condições artificiais de oferta e demanda; (ii) manipulação de preços; (iii) realização de operações fraudulentas; (iv) práticas não eqüitativas.

A idéia de abordar o tema em um trabalho monográfico de final de curso surgiu a partir de uma pesquisa realizada no decorrer de estágio realizado em um escritório de advocacia especializado em Direito Societário e Mercado de Capitais. Na ocasião, foi constatada a grande deficiência bibliográfica existente em relação a este assunto.

Não obstante essa deficiência, o tema é de grande relevância para atuação do operador do Direito que decide militar neste ramo da Ciência Jurídica. Tal relevância é constatada pela existência de inúmeros processos administrativos instaurados pela autarquia ${ }^{1}$.

Além disso, fica evidente uma certa confusão realizada entre os tipos definidos na referida Instrução Normativa, a começar pelo texto inicial da nota explicativa na qual a autarquia explicita os motivos de criação da referida norma, como segue: "a necessidade de evitar modalidade de fraude $e$ manipulação destinadas a criar condições artificiais de demanda, oferta ou preço de títulos ou valores mobiliários distribuídos no mercado, bem como a

\footnotetext{
1 Desde 2004, foram instaurados mais de 100 processos administrativos sancionadores no âmbito da Comissão de Valores Mobiliários que versavam sobre o tema que ora se pretende analisar.
} 
exigência de que fossem observadas práticas comerciais equitativas no mercado de capitais (...)".

A referida nota explicativa afirma, ainda, que os ilícitos acima citados refletem "modelo similar ao utilizado pelo próprio Código Penal no tocante a certos crimes, como os crimes contra o patrimônio, onde são incluídas figuras típicas de conteúdo bastante amplo, denominados 'tipos abertos'.,

Deste modo, é imperiosa uma análise detalhada dos institutos referidos na Instrução CVM $n^{\circ}$ 08/1979, a fim de que seja feita uma adequada classificação e sistematização das condutas ilícitas passíveis de punição na esfera administrativa.

\section{2 - Delimitação do Tema}

A temática a ser analisada no presente trabalho relaciona-se diretamente com a Instrução CVM n ${ }^{\circ}$ 08/1979, editada para tipificar, no âmbito do direito administrativo sancionador, os ilícitos de manipulação de mercado, operações fraudulentas e prática não eqüitativa.

Vale dizer, a prática de insider trading - ilícito consistente na negociação de valores mobiliários com posse de informação pivilegiada; ou seja, uma informação da qual os outros agentes no mercado não dispõem -, não será abordada neste trabalho. O motivo é que, ao contrário dos ilícitos sobre os quais se pretende focar nesta monografia, o chamado insider trading é tema bastante ventilado na doutrina e na jurisprudência. Incluí-lo no objeto desta pesquisa não traria grandes inovações ao que já foi publicado, e tiraria o foco do que se pretende de fato analisar.

Partindo dessa introdução, onde são abordadas considerações básicas sobre o tema, o segundo capítulo pretende fazer breves considerações históricas sobre a regulação do Mercado de Valores Mobiliários brasileiro. Serão abordadas as idéias de mercado eficiente, se os mercados são atualmente 
considerados eficientes, o porque da ineficiência que se verifica em alguns casos, e, além disso, os objetivos da atuação estatal na regulação e fiscalização dos mercados.

Partindo da premissa de que toda atividade estatal guarda valores a ela intrínsecos, tentar-se-á descobrir quais são estes valores, inerentes à atuação do ente regulador brasileiro. O capítulo abordará, ainda, quais são as condições para um funcionamento adequado dos Mercados de Valores Mobiliários. Pretende-se buscar requisitos de fundamental relevância para que os mercados possam funcionar livremente. Entre eles, encontram-se a eficiência, em seus mais variados aspectos, entre eles, a existência de sistemas capazes de formular um ambiente de negócios sólido e seguro, no qual compradores e vendedores podem realizar suas operações com tranquilidade; a ampla informação, tida como fundamental para o adequado desenvolvimento do mercado, que conte com participação cada vez maior do investidor não institucional, e até mesmo do investidor não qualificado e, ainda, determinante para que todos os atores de mercado possam tomar sua livre decisão de investimento; e, por fim, a proteção dos investidores, fim último da regulação do mercado de valores mobiliários.

O terceiro capítulo pretende realizar uma análise detalhada das infrações previstas na Instrução CVM nº 08/1979. Começando por uma análise dos requisitos previstos na Lei 6.385/1976 para a tipificação do crime de manipulação de mercado, pretende-se descobrir quais são os elementos indispensáveis à sua caracterização. A mesma análise será realizada com os textos normativos norte-americano e português, sempre tentando inferir quais são os requisitos básicos para delimitação dos conceitos do ilícito de manipulação de mercado nesses países.

A partir dessa análise, voltar-se-ão os olhos para a tipificação administrativa dos ilícitos, tal qual foi promovida pela Instrução CVM 08/1979, mantendo um posicionamento crítico sobre os institutos e definido os 
requisitos para que cada uma deles ocorra, atentando para o que dispõem as decisões da Comissão de Valores Mobiliários, conflitando as diferentes decisões disponíveis.

Longe da pretensão de esgotar o tema - que, como dito, possui relevância central no estudo do Direito dos Valores Mobiliários -, o que se pretende com este trabalho é muito mais estimular a discussão sobre um ponto que, apesar da importância, é pouco discutido na doutrina brasileira.

\section{3 - Metodologia}

Durante as pesquisas para este trabalho monográfico, foi constatada a parca e incompleta bibliografia existente em relação ao tema. Por outro lado, dada a relevância do tema para a aplicação do Direito dos Valores Mobiliários, há uma ampla gama de decisões proferidas pela Comissão de Valores Mobiliários em Processos Administrativos Sancionadores, nas quais a autarquia discute questões concernentes ao tema. Por este motivo, será realizada uma análise da legislação relacionada ao tema, além das decisões no âmbito da Comissão da Valores Mobiliários. Tentar-se-á, ainda, extrair elementos do tipo penal Manipulação de Mercado, recém incluso na lei 6.385/1976. Além disso, serão utilizadas referências de Direito Comparado e Internacional. 


\section{Capítulo 2 - Condições para um funcionamento adequado do mercado de valores mobiliários}

\section{1 - Noção de mercado perfeito, imperfeições e finalid ade da regulação estatal}

Um mercado pode ser definido como um local, físico ou não, onde compradores e vendedores se reúnem para negociar ativos, títulos, e outros. Desde mercados locais, onde produtores agrícolas se encontram com varejistas para negociar gêneros alimentícios ${ }^{2}$, até os mercados de bolsa mais sofisticados do mundo, que negociam diariamente bilhões de dólares, nosso cotidiano se depara freqüentemente com esse fato social.

O Mercado de Capitais é definido como o mercado onde a mobilização da poupança se dá diretamente entre o ente superavitário - que possui sobra de recursos - e o ente deficitário - que, em regra, precisa de mais recursos do que dispõe.

É também entendido como o mercado da desintermediação bancária. Isso se dá pelo fato de ser o único mercado onde as instituições financeiras figuram como meros intervenientes na relação entre o investidor e o tomador de recursos ${ }^{3}$.

Ou seja, quando "uma companhia emite publicamente uma ação, apesar de ser obrigatória a participação de uma instituição financeira na operação, do

\footnotetext{
${ }^{2}$ Estudo mu ito interessante, intitulado "A construção social de um mercado perfeito: o caso de Fontaines -en-sologne”, de autoria de Marie France Garcia-Parpet, disponível em <http://bibliotecavirtual.clacso.org.ar/ar/libros/brasil/cpda/estudos/vinte/parpet20.htm >, a nalisa um mercado francês de morangos, suas características e o compara com o modelo perfeito de mercado. ${ }^{3}$ Nesse sentido, MOSQUERA, Roberto Quiroga. Os Princípios Informadores do Direito do Mercado Financeiro e de Capitais. In: MOSQUERA, Roberto Quiroga (Org.). Aspectos Atuais do Direito do Mercado Financeiro e de Capitais. São Paulo: Dialética, 1999, p. 260.
} 
ponto de vista jurídico, o subscritor adquire a ação diretamente da companhia."4

O Mercado de Capitais pode ser ainda considerado um mercado de longo prazo, na medida em que, em regra, os recursos aplicados pelo investidor servem como capital para que o ente deficitário invista em seu negócio e, obtendo sucesso, distribua os lucros desse empreendimento àquele que lhe colocou à disposição tais recursos.

Para entender os objetivos e finalidades da regulação do Mercado de Capitais, é necessário que se proceda a uma análise do que seria sua forma ideal.

Para Leslie Amendolara, o mercado perfeito é

"aquele em que os preços necessariamente estarão sempre refletindo, naquele momento, a vontade dos investidores de comprar ou vender um valor mobiliário, segundo a lei da oferta e da procura, sem gozar de nenhuma informação privilegiada ou utilizar-se de manipulação."

É conhecida a teoria de Adam Smith, segundo a qual existe uma mão invisível, responsável pela regulação dos mercados, que corrigiria naturalmente suas falhas e distribuiria riquezas a todos os seus participantes.

Porém, tal idéia é refutada atualmente, principalmente devido ao fato de que a falta de regulação em alguns mercados, notadamente o de valores mobiliários, produziu efeitos perversos na economia internacional, sendo apontada por alguns estudiosos americanos como responsável pela Grande Depressão de $1929^{6}$.

\footnotetext{
${ }^{4}$ CHEDIAK, Julian Fonseca Peña, A Reforma do Mercado de Valores Mobiliários, in: LOBO, Jorge, Reforma da Lei das Sociedades Anônimas: Inovações e Questões Controvertidas da Lei $\mathrm{n}^{\circ} 10.303$, de 31.10.2001. Rio de Janeiro: Forense, 2002, p. 531-532.

${ }^{5}$ AMENDOLARA, Leslie. Fundamentos e Objetivos da Regulamentação do Sistema de Informação de Sociedades que fazem Ofertas Públicas. In: VII Congreso Argentino de Derecho Societario y III Congresso Iberoamericano de Derecho Societario y de la Empresa. La Sociedad Comercial ante El tercer milênio, Buenos Aires, p. 6.

${ }^{6}$ SZTAJN, Rachel. Regulação e o Mercado de Valores Mobiliários. Revista de Direito Mercantil, Industrial, Econômico e Financeiro. São Paulo, n. 135, jul-set/2004, p. 139.
} 
Vale dizer, a crise que se vive atualmente no mercado financeiro internacional foi gerada, em boa arte, pela ausência de fiscalização, por parte das autoridades reguladoras norte-americanas, das atividades de escrituração e contabilização de recebíveis ligados às hipotecas de alto risco (comumente chamadas de subprime).

Por isso, Rachel Sztajn afirma que,

"na realidade, mercados de concorrência perfeita são poucos, abundando aqueles em que há falhas, estruturais ou comportamentais, falhas essas que produzem custos de transação, por isso é preciso corrigitlas e um dos mecanismos a que se pode recorrer é a regulação",

Com efeito,

“(...) o mercado eficiente promove a alocação eficaz da poupança no setor produtivo e conseqüientemente o crescimento econômico. As forças espontâneas do mercado e a soma dos interesses privados, porém, nem sempre são suficientes para assegurar o funcionamento regular do mercado. Daí surge a necessidade de intervenção regulatória (....", .

Por isso, diz-se com freqüência, que a regulação estatal dos mercados de capitais surge para suprir tais deficiências, no sentido de tentar minimizar a discrepância de informações disponíveis aos diferentes participantes do mercado.

De um modo geral, a regulação estatal "pode ser entendida como o conjunto de regras predispostas por um órgão ou agência da administração indireta, visando a fiscalizar e garantir, pela observância ou cumprimento, a disciplina de certas atividades ou setores da atividade econômica"9

Diz-se, ainda, que

"a finalidade da regulação do mercado de capitais, como a de qualquer outro, é fazê-lo apresentar eficiência alocacional e eficiência operacional. Isto é, fazer com

\footnotetext{
${ }_{8}^{7}$ Ibid., p. 137.

${ }^{8}$ PARENTE, Norma. A Regulação e o desenvolvimento do Mercado de Capitais. Revista de Direito Bancário, do Mercado de Capitais e da Arbitragem. São Paulo: Revista dos Tribunais, n. 18, outdez/2002, p. 247.

${ }^{9}$ SZTAJN, Op. Cit., p. 137.
} 
que os recursos alocados em tal mercado obtenham o máximo retorno e que o processo de alocação dos recursos se dê ao custo mais baixo."10

Para cumprir tais objetivos e atender a tais finalidades, dispõe a Administração Pública de três poderes inerentes à regulação. São eles (i) o de editar regras; (ii) o de assegurar sua aplicação e (iii) o de reprimir as infrações $^{11}$.

Fica claro, assim, o caráter limitador que assume a regulação sobre a atividade privada sobre os interesses dos seus administrados.

Essa limitação se dá, geralmente, em função de um interesse coletivo, qual seja, a defesa do mercado e seu regular e adequado funcionamento.

Vale transcrever um trecho da exposição de motivos da Lei 6.385/1976 - que regula o mercado de valores mobiliários ${ }^{12}$ :

"A experiência demonstrou que a defesa da economia popular e o funcionamento regular do mercado de capitais exigem a tutela do Estado, com a fixação de normas para a emissão de títulos destinados ao público, divulgação de dados sobre a companhia emitente e negociação dos títulos no mercado. Além disso, é necessário que agência governamental especializada exerça as funções de polícia do mercado, evitando as distorções e abusos a que está sujeito." ${ }^{33}$

Porém, a atividade regulatória deve ser realizada com moderação. A despeito de sua importância, ela representa, de fato, uma limitação sobre a iniciativa privada. Em que pese os seus efeitos positivos, muito cuidado deve ser tomado, pois um aumento excessivo na regulação, com regras formais desnecessárias ou meramente burocráticas, traria efeitos perversos para o

\footnotetext{
${ }^{10}$ EIZIRIK, Nelson. Regulação e Auto-regulação do mercado de valores mobiliários. Revista de Direito Mercantil, Industrial, Econômico e Financeiro. São Paulo: Malheiros Editores, n. 48, outdez/1982, p. 49.

${ }^{11}$ Nesse sentido, ARAGÃO, Alexandre dos Santos, O Conceito Jurídico de Regulação da Economia. Revista de Direito Mercantil, Industrial, Econômico e Financeiro. São Paulo: Malheiros Editores, n. 122, abr-jun/2001, p. 40.

${ }^{12}$ Tal lei será comentada com maior atenção no capítulo 3.

${ }^{13}$ Publicada em Diário Oficial no dia 10.08.1976, p. 6974.
} 
mercado, aumentando em demasia os custos de produção e desincentivando a atividade econômica.

Pode-se dizer então que, nesses casos, a regulação estaria se distanciando do seu objetivo principal, que é aumentar a eficiência do mercado.

Com efeito, os impactos mais adversos que se pode notar na regulação pouco eficiente são: (i) fuga de capitais, principalmente por conta de custos regulatórios excessivos; (ii) desenvolvimento insuficiente dos mercados; e (iii) redução do ritmo de inovação dos produtos e serviços financeiros ${ }^{14}$.

Nesse sentido, muitos sistemas jurídicos têm adotado a auto-regulação como forma concomitante e complementar à regulação estatal. Consiste aquela na "normatização e físcalização, por parte dos próprios membros do mercado, organizados em instituições ou associações privadas, de suas atividades, com vistas à manutenção de elevados padrões éticos."15

Como este modelo regulatório é praticado pelos próprios entes regulados, guarda inúmeras vantagens em relação à regulação estatal. Um exemplo claro é que, os participantes daquele mercado regulado geralmente têm um conhecimento muito maior sobre a atividade nele desenvolvida. Assim, têm maiores chances de promover uma regulação bem sucedida, sem custos regulatórios exagerados e desnecessários.

Entretanto, há um conflito de interesses evidente em tal atividade, na medida em que os próprios regulados - ou seja, ou sujeitos passíveis de fiscalização e sanção pela auto-reguladora - fazem parte da entidade responsável pela auto-regulação. Por isso, há a necessidade de conviverem os dois sistemas - regulação estatal e auto-regulação - em perfeita harmonia.

Outro aspecto de grande relevância da atividade regulatória é que ela nunca está dissociada da realidade do país na qual o ente regulador e seus

\footnotetext{
${ }^{14}$ Nesse sentido, ver PARENTE, Op. Cit., p. 248.

${ }^{15}$ EIZIRIK, Op. Cit., p. 52.
} 
regulados estão inseridos. Por isso, deve-se atentar para o fato de que a regulação terá sempre um caráter político envolvido.

Assim, a intervenção estatal na economia se dá sempre em função dos interesses e anseios daquela sociedade, expressos mediante a atuação do Estado que a representa.

É possível afirmar, portanto, que a atividade de regulação do mercado de capitais, assim como a de qualquer outro, é eminentemente política ${ }^{16}$, porque resulta vontade do ente estatal em determinar condutas desejadas, estimulando certas atividades e coibindo outras tantas.

Vale dizer, tais intervenções não podem deixar de lado as características específicas daquele setor econômico sobre o qual se está intervindo.

Dado esse caráter político da atividade regulatória, devemos buscar conhecer quais são os valores que estão por trás daquela sociedade e, por conseqüência, do Estado responsável pela regulação dos mercados.

Dentro da Filosofia Jurídica, pode-se dizer que os princípios jurídicos são imperativos de caráter abstrato, que se espraiam por todo o sistema e informam os valores que o criador ou o operador do Direito devem buscar no seio de sua atividade.

Assim, os "princípios são ordenações que se irradiam e imantam os sistemas de normas são [como observam Gomes Canotilho e Vital Moreira] 'núcleos de condensações' nos quais confluem valores $e$ bens constitucionais." 17

Por isso, os princípios jurídicos, sejam positivados ou não, assumem papel de grande relevância dentro do ordenamento jurídico, por serem imperativos de caráter fundamental, representando assim a base de qualquer sistema jurídico.

\footnotetext{
${ }^{16}$ CHEDIAK, Op. Cit., p. 528. No mesmo sentido, EIZIRIK, Op. Cit., p. 48.

${ }^{17}$ SILVA, José Afonso da. Curso de Direito Constitucional Positivo. $24^{\text {a }}$ ed. São Paulo: Malheiros, 2005. p. 92
} 
Esse caráter fundamental dos princípios pode ser confirmado pelo fato de que boa parte deles está geralmente disposto nas constituições dos Estados.

Com efeito,

"a identificação dos princípios jurídicos que norteiam o direito do mercado financeiro e de capitais deve percorrer toda a estrutura normativa hierarquizada acima apontada, com o intuito de extrair do texto normativo, seja ele qual for, as prescrições fundamentais do referido sistema jurídico." 18

\section{2 - Princípios norteadores da atuação regulatória no âmbito do Mercado de Valores Mobiliários}

A Lei 6.385/1976, que criou a Comissão de Valores Mobiliários e constitui marco jurídico para a disciplina do mercado de capitais brasileiro, estabelece, em seu artigo $4^{\circ}$, o seguinte:

"Art . 4 ${ }^{\circ}$ O Conselho Monetário Nacional e a Comissão de Valores Mobiliários exercerão as atribuições previstas na lei para o fim de: mobiliários;

I - estimular a formação de poupanças e a sua aplicação em valores

II - promover a expansão e o funcionamento eficiente e regular do mercado de ações, e estimular as aplicações permanentes em ações do capital social de companhias abertas sob controle de capitais privados nacionais; bolsa e de balcão;

III - assegurar o funcionamento eficiente e regular dos mercados da

IV - proteger os titulares de valores mobiliários e os investidores do mercado contra:

a) emissões irregulares de valores mobiliários;

b) atos ilegais de administradores e acionistas controladores das companhias abertas, ou de administradores de carteira de valores mobiliários. mobiliários.

c) o uso de informação relevante não divulgada no mercado de valores

V - evitar ou coibir modalidades de fraude ou manipulação destinadas a criar condições artificiais de demanda, oferta ou preço dos valores mobiliários negociados no mercado;

VI - assegurar o acesso do público a informações sobre os valores mobiliários negociados e as companhias que os tenham emitido;

VII - assegurar a observância de práticas comerciais equitativas no mercado de valores mobiliários;

VIII - assegurar a observância no mercado, das condições de utilização de crédito fixadas pelo Conselho Monetário Nacional."

${ }^{18}$ MOSQUERA, Op. Cit., p 262-263. 
Ao estabelecer as finalidades de atuação da Comissão de Valores Mobiliários e do Conselho Monetário Nacional, o legislador ordinário brasileiro contribuiu para a definição de quais seriam princípios fundamentais da atividade do órgão regulador.

O Código de Valores Mobiliários português, republicado pelo DecretoLei n. ${ }^{\circ}$ 357-A/2007, de 31 de Outubro, estabelece, em seu artigo 358, princípios informadores da supervisão da Comissão de Mercado de Valores Mobiliários:

“a) Protecção dos investidores; financeiros

b) Eficiência e regularidade de funcionamento dos mercados de instrumentos

c) Controlo da informação;

d) Prevenção do risco sistémico;

e) Prevenção e repressão das actuações contrárias a lei ou a regulamento; supervisão." 19

f) Independência perante quaisquer entidades sujeitas ou não à sua

Roberto Quiroga afirma que os princípios que conduzir a atividade de regulação dos mercados financeiro e de capitais são: (i) proteção da mobilização da poupança nacional; (ii) proteção da economia popular; (iii) proteção da estabilidade das entidades financeiras; (iv) proteção do sigilo bancário e (v) proteção da transparência de informações ${ }^{20}$.

Por sua vez, Nelson Eizirik afirma que as finalidades da regulação do mercado de capitais devem ser os seguintes:

(i) eficiência na determinação do valor dos títulos negociados. Para tal,

o preço dos títulos deve refletir apenas as informações publicamente disponíveis;

\footnotetext{
${ }^{19}$ Disponível em www.cmvm.pt.

${ }^{20}$ MOSQUERA, Op. Cit., p. 271.
} 
(ii) efic iência nas transferências dos títulos entre os investidores. Para que isso seja possível, a regulação deve tentar estabelecer custos de transação reduzidos o tanto quanto possível;

(iii) a entidade reguladora deve evitar a concentração de poder econômico, o que causaria redução na competição necessária ao bom funcionamento de qualquer mercado; e

(iv) a regulação do mercado de capitais deve tentar evitar a ocorrência de situações de conflito de interesses ${ }^{21}$.

Portanto, sem pretender esgotar o tema, de relevância nevrálgica para o estudo do mercado, é possível estabelecer condições para o funcionamento adequado dos mercados de valores mobiliários e, que, portanto, devem nortear a atuação da CVM. São elas as seguintes:

(i) Eficiência

(ii) Informação

(iii) Proteção ao investidor

É de se ressaltar que tais condições congregam uma série de valores, podendo ser considerados verdadeiros princípios para um adequado funcionamento do mercado de valores mobiliários.

Vale dizer, mesmo com relação a esses princípios, aparentemente autônomos, surgirão situações onde a distinção é muito tênue, às vezes praticamente inexistente.

Entendemos que todas as condições e princípios acima elencados representam, de uma ou outra forma, em maior ou menor medida, os princípios e finalidades acima estabelecidos pelas legislações e juristas citados.

${ }^{21}$ EIZIRIK, Op. Cit., p. 49-50. 
Por exemplo, alguns autores defendem que ser o funcionamento regular dos mercados um princípio norteador da atuação estatal regulatório. Porém, tal princípio é muito amplo, excessivamente abrangente e aberto.

Com efeito, pode-se dizer que qualquer intervenção estatal deve ser produzida dentro de qualquer mercado deve ser com vistas ao seu funcionamento regular, seja na disseminação de informações, aumento de eficiência ou mesmo na proteção aos investidores.

Por isso, é possível afirmar que tal princípio está de alguma forma inserido em todos os outros mencionados.

\subsection{1 - Eficiência}

Utilizando-se das lições de Nelson Eizirik, já apontadas acima, é possível elencar dois aspectos fundamentais dentro do conceito de Eficiência. Ambos são de grande relevância na disciplina do mercado de valores mobiliários.

São eles a eficiência alocacional e a eficiência operacional.

O primeiro - eficiência alocacional - significa que o mercado deve ser eficiente na alocação dos recursos dos particulares. Ou seja, que o mercado deve refletir de um modo mais adequado possível as forças de compra e venda, e que o preço de determinado todas as informações

Nesse sentido, é possível afirmar que "um dos pressupostos fundamentais do funcionamento dos mercados de valores mobiliários consiste na ideia da incorporação da informação disponível na negociação dos activos (...)."22

Esse primeiro aspecto relaciona-se diretamente com o princípio da informação e será melhor desenvolvido abaixo, no item 2.2.2.

\footnotetext{
22 PINTO, Frederico Costa. O Direito de Informar e os Crimes de Mercado. Cadernos do Mercado de Valores Mobiliários, n. $^{\circ} 21^{\circ}{ }^{\circ}$ semestre de 1998, CMVM, Lisboa, p. 98
} 
O segundo - eficiência operacional - refere-se à redução dos custos operacionais que deve ser buscada pela autoridade reguladora a fim de que os mercados sejam mais competitivos, tanto entre os participantes do mercado brasileiro quanto entre o mercado brasileiro e os internacionais.

Um aumento na competição entre participantes do mercado, especialmente entre intermediários financeiros, é essencial para que se busque ainda mais eficiência, na medida em que estes tendem a diminuir seus preços a fim de angariar novos clientes.

\subsection{2. - Informação}

Segundo a hipótese dos mercados eficientes, trazida pela literatura econômica $^{23}$, o preço de qualquer ativo reflete as informações sobre ele disponíveis naquele determinado momento e local.

Sendo assim, é possível dizer que um título que seja negociado em um mercado qualquer tem seu preço determinado pelas informações disponíveis sobre a companhia a qual ele representa, sobre o ramo de negócios onde ela atua ou, ainda, sobre a economia como um todo na qual ela está inserida.

$\mathrm{Ou}$ seja, quando ocorre a divulgação de notícias positivas sobre a determinada companhia, seu ramo de atuação ou sobre a economia como um todo, ou mesmo sobre alguma companhia específica, seus títulos da empresa sejam de participação, de dívida ou qualquer outro - refletem aquela informação, através de um aumento no seu preço.

Por outro lado, se ocorre a disseminação no mercado de informações negativas sobre a economia, sobre determinada empresa ou seu ramo de negócios, o preço de seus títulos tende a cair.

\footnotetext{
${ }^{23}$ MANKIW, N. Gregory. Introdução à Economia. [tradução Allan Vidigal Hastings], $3^{\text {a }}$ Ed., São Paulo: Pioneira Thomson Learning, 2005, p. 592.
} 
Isto porque, quando são divulgadas notícias positivas sobre determinada companhia, aumenta a perspectiva do mercado de que ela irá apresentar um resultado favorável. Assim, um número maior de pessoas se interessa em adquirir parte dela - uma ação, por exemplo -, aumentando a demanda por tais títulos. Ao mesmo tempo, investidores que os detêm - que poderiam se interessar por vendê-lo - só irão querer se desfazer deles por um preço maior.

O raciocínio inverso vale para informações negativas. Quando da sua divulgação, um número menor de pessoas irá querer participar de um negócio com perspectivas ruins. Talvez só participem pagando um preço menor. Os vendedores terão maior interesse em se desfazer daquele título, recebendo preços menores do que aceitariam antes de tal divulgação.

Isso se dá, naturalmente, porque a demanda por algum ativo é maior quando há um certo do mercado consenso sobre as boas perspectivas do negócio que aquele representa, e menor quando esse consenso aponta para perspectivas negativas. ${ }^{24}$

Entretanto, há que se ressaltar que as informações nem sempre estão disponíveis de forma igual para todos os participantes do mercado. É possível afirmar, na verdade, que a assimetria de informação é regra no mercado de capitais $^{25}$.

Com efeito, "o equilíbrio automático que seria conseguido pelo funcionamento do mercado é, de facto, substancialmente perturbado pela existência de assimetrais de informação que vão determinar uma alocação imperfeita da riqueza" ${ }^{26}$.

Por isso,

\footnotetext{
${ }^{24}$ Entretanto, a hipótese dos mercados eficientes sugere que, quando uma notícia é divulgada, o mercado absorve tal situação instantaneamente, de modo que os preços logo passam a refletir aquela nova informação. Desse modo, não faria sentido que se procedesse à compra/venda desse ativo. ${ }^{25}$ AMENDOLARA, Op. Cit., p. 10.

${ }^{26}$ FERREIRA, Eduardo Paz, A informação no Mercado de Valores Mobiliários, in: Direito dos Valores Mobiliários. Coimbra: Coimbra Editora, 2001, p. 143-144.
} 
"Ao impor deveres de prestação de informação, o legislador pretende eliminar (ou, ao menos, reduzir significativamente) essas assimetrias, consagrando o princípio da igualdade no acesso à informação - obrigando quem tem a informação a partilhá-la com quem a não tem, especialmente o público investidor ${ }^{27,}$

Assim, é possível perceber que daí decorre a importância do segundo princípio fundamental qual seja, o da ampla informação.

$\mathrm{Na}$ verdade, alguns autores consideram que o princípio da informação estaria inserido dentro do princípio da eficiência, especialmente porque "Esencialmente, el mercado será eficiente em tanto y em cuanto exista La más amplia información o transparência normativa" ${ }^{28}$.

Vale dizer, como ressaltado no item anterior, o princípio da informação está diretamente relacionado com a eficiência em seu aspecto alocacional. Porém, não se deve confundi-los.

Além disso, dada a importância que tem esse princípio da informação na condução das atividades regulatórias e, de um modo geral, no Direito dos Valores Mobiliários, faz-se necessária a separação entre os dois princípios.

Com efeito,

“(...) o mercado vive de informação, mas nem sempre a produz espontaneamente, em tempo oportuno e com a qualidade necessária. Por isso mesmo, justifica-se a intervenção do legisla dor nesta matéria, no sentido de estabelecer um conjunto de deveres de prestação de informação ao mercado, aos investidores e às autoridades de supervisão (...)., ${ }^{29}$

O princípio da informação e, por conseguinte, o direito à informação, assume segundo a doutrina, a posição de "um direito de carácter instrumental,

\footnotetext{
${ }^{27}$ REIS, Célia e SANTOS, Felipe. Divulgação de Informação. Cadernos do Mercado de Valores Mobiliários, n. ${ }^{\circ}$ 28, dez/2007, CMVM, Lisboa, p. 182.

${ }^{28}$ ROMANO, Alberto Antonio. Princípios Rectores Del Mercado de Capitales (Lo Elemental para su Eficiência). In: VII Congreso Argentino de Derecho Societario y III Congresso Iberoamericano de Derecho Societario y de la Empresa. La Sociedad Comercial ante El tercer milênio, Buenos Aires, p. 73.

${ }^{29}$ PINTO, Op. Cit., p.98.
} 
acessório de outros direitos societários, concebido para permitir o exercício destes em termos concretos" ${ }^{30}$. Por isso sua importância.

\subsection{3 - Proteção aos investidores}

A proteção aos investidores é um dos princípios mais importantes, e um dos mais comentados na doutrina nacional e estrangeira especializada no Direito dos Valores Mobiliários.

Desse, é possível afirmar que proteger os investidores, principalmente aos não profissionais, os quais não têm tantas condições de fazer uma análise profunda dos títulos nos quais pretendem investir, deve ser o fim último e mais importante da regulação estatal.

Ademais, a proteção aos investidores pode ser considerada como proteção ao próprio mercado.

Isto porque, na medida em que, se os aplicadores de recursos não se sentirem seguros com relação às medidas tomadas pela autoridade reguladora, tanto na fiscalização do mercado quanto na aplicação de sanções às transgressões de suas regras, esses investidores podem fugir daquele mercado.

Se esse sentimento de insegurança é compartilhado por muitos investidores, pode haver fuga de capitais e, por conseqüência, a quebra de todo o sistema.

"Segurança do investimento e a confiança no mercado são, portanto, condições essenciais ao regular funcionamento deste pois dela depende a decisão do investidor no sentido de aplicar, neste mercado, as suas poupanças. "31

\footnotetext{
${ }^{30}$ FERREIRA, Op. Cit., p. 139.

${ }^{31}$ RODRIGUES, Sofia Nascimento Rodrigues, A Protecção dos Investidores em Valores Mobiliários, Coimbra: Almedina, 2001, p. 26.
} 
Vale dizer, ainda, que o princípio da informação, bem como o dever de informar por parte dos participantes do mercado, especialmente administradores e intermediários financeiros, guarda estreitas relações com o princípio de proteção aos investidores.

Com efeito,

"O dever de informação permanente funciona como um meio de realização de um fim último de protecção dos investidores, promovendo o funcionamento eficiente, equitativo e transparente do mercado de valores mobiliários. É um mecanismo legal que visa (...) obrigar as sociedades cotadas a criarem um mercado eficiente e transparente para os valores que emitem"32

É possível afirmar, ainda, que "Noutra perspectiva, poderá, também, dizer-se que a ausência de informação poderá pôr em causa o funcionamento do mercado criando um risco sistêmico que retrairá os investidores." 33

É importante ressaltar, ainda, como visto acima, constitui elemento de suma importância no que tange a proteção aos investidores a credibilidade do mercado, bem como a confiança que os investidores nele mantém. Tal elemento guarda relações também com a eficiência do mercado, na medida em que uma maior segurança reduz a percepção de risco por parte dos participantes do mercado, deixando-os mais seguros para investir e contribuindo para uma melhor formação precificação dos ativos.

\footnotetext{
32 PEREIRA, José Nunes. O Novo Código dos Valores Mobiliários e a Protecção dos Investidores, in Cadernos do Mercado de Valores Mobiliários, n. ${ }^{\circ}$ 7, Lisboa, 2000, p. 78.

${ }^{33}$ FERREIRA, Op. Cit., p. 144-145.
} 


\section{Capítulo 3 - llícitos no Mercado de Valores Mobiliários}

\section{1 - Histórico e Caracterização na legislação brasileira}

O primeiro texto normativo que faz menção aos ilícitos no mercado é a Lei 1.521, de 26 de dezembro de 1951, comumente chamada de Lei dos Crimes contra a Economia Popular. Diz a referida norma o seguinte:

“Art. $3^{\circ}$. São também crimes desta natureza: (...)

VI - provocar a alta ou baixa de preços de mercadorias, títulos públicos, valores ou salários por meio de notícias falsas, operações fictícias ou qualquer outro artifício;

VII - dar indicações ou fazer afirmações falsas em prospectos ou anúncios, para fim de substituição, compra ou venda de títulos, ações ou quotas;" (grifos nossos)

A doutrina defende que o artigo supra citado teve aplicação difícil no âmbito da disciplina do mercado de capitais, uma vez que não só exige a demonstração do artifício empregado, como também a efetiva alta ou baixa dos preços dele decorrente ${ }^{34}$.

Por mais vago que fosse o dispositivo, abrangendo condutas das mais diversas, tal norma foi utilizada em alguns processos contra investidores no mercado de capitais, sendo responsável por condenações em casos de grande relevância.

Por exemplo, alguns indivíduos, incluindo o megainvestidor Naji Nahas, foram condenados, em 08 de outubro de 1997, com base na referida lei, "pelo

\footnotetext{
${ }^{34}$ Nesse sentido, ver EIZIRIK, Nelson et atl. Mercado de Capitais Regime Jurídico. $2^{\text {a }}$ Ed., Rio de Janeiro: Renovar, 2008, p. 521-522.
} 
fato de induzirem terceiros a negociarem valores mobiliários com as cotações manipuladas diante de esquema orquestrado,35

A despeito de já existir tal previsão legislativa a respeito de ilícitos no mercado, a primeira vez que ocorreu uma tentativa de sistematizar tal conduta dentro das regras do mercado de capitais foi com a Lei 4.728, de 1965. Com efeito, esse diploma foi o primeiro em nosso país que ditou regras para o então incipiente mercado brasileiro.

Dizia a referida Lei:

"Art. $2^{\circ} \mathrm{O}$ Conselho Monetário Nacional e o Banco Central exercerão as suas atribuições legais relativas aos mercados financeiro e de capitais com a finalidade de: III - evitar modalidades de fraude e manipulação destinadas a criar condições artificiais da demanda, oferta ou pre ço de títulos ou valôres mobiliários distribuídos no mercado;

IV - assegurar a observância de práticas comerciais equitativas por todos aquêles que exerçam, profissionalmente, funções de intermediação na distribuição ou negociação de títulos ou valôres mobiliários;" (grifos nossos)

Dizia ainda a lei, no que diz respeito às regras a serem editadas para as bolsas de valores:

"Art. $7^{\circ}$ Compete ao Conselho Monetário Nacional fixar as normas gerais a serem observadas na constituição, organização e funcionamento das Bôlsas de Valôres, e relativas a:

$\mathrm{V}$ - normas destinadas a evitar ou reprimir manipulações de preços e operações fraudulentas ; condições a serem observadas nas operações autorizadas de sustentação de preços;

Por fim, definia a competência do órgão então responsável pela regulação do mercado de capitais, como segue:

"Art. 10. Compete ao Conselho Monetário Nacional fixar as normas gerais a serem observadas no exercício das atividades de subscrição para revenda,

\footnotetext{
${ }^{35}$ SANCTIS, Fausto Martin de. Punibilidade no Sistema Financeiro Nacional: Tipos penais que tutelam o sistema financeiro nacional, incluindo o mercado de capitais. Campinas-SP: Millennium, 2003, p. 98.
} 
distribuição, ou intermediação na colocação, no mercado, de títulos ou valôres mobiliários, e relativos a:

VII - normas destinadas a evitar manipulações de preço e operações fraudulentas ;" (grifos nossos)

Fica claro então que, com a Lei 4.728/1965, buscava o legislador brasileiro reprimir dois tipos de conduta, quais sejam a (i) manipulação no mercado de valores mobiliários, caracterizada pela criação de condições artificiais de demanda, oferta e preço; e a (ii) realização de operações fraudulentas no mercado de valores mobiliários.

Visava também o legislador a incentivar a adoção de práticas comerciais equiitativas, ou seja, transferir as práticas de comércio adotadas no Brasil também para o mercado de valores mobiliários.

Com a edição da Lei 6.385, de 7 de dezembro de 1976, norma que criou a CVM e que é responsável pela atual regulação do mercado de valores mobiliários brasileiro, foi também estabelecido o rol de finalidades do regulador do mercado, como segue:

"Art . 4 $\mathrm{O}$ Conselho Monetário Nacional e a Comissão de Valores Mobiliários exercerão as atribuições previstas na lei para o fim de: (...)

$\mathrm{V}$ - evitar ou coibir modalidades de fraude ou manipulação destinadas a criar condições artificiais de demanda, oferta ou preço dos valores mobiliários negociados no mercado;

(...) VII - assegurar a observância de práticas comerciais equitativas no mercado de valores mobiliários;" (grifos nossos)

Vê-se, claramente, que os incisos V e VII do artigo $4^{\circ}$ da lei 6.385/1976 reproduziram fielmente o disposto nos incisos III e IV do artigo $2^{\circ}$ da antiga lei 4.728/1965, a não ser por detalhes no final do inciso IV, que não interferem na análise que ora se pretende.

Conclui-se, então, que a finalidade da atuação do órgão regulador do mercado de valores mobiliários brasileiro - antes o Conselho Monetário Nacional, ora a Comissão de Valores Mobiliários - permaneceu praticamente a 
mesma no que se refere à regulação e repressão de condutas nocivas ao mercado.

Ainda a respeito da matéria ora referida, a lei 6.385/1976, como fazia sua antecessora, prevê competências normativas específicas à CVM. Com efeito, dispõe a norma:

“Art. 18. Compete à Comissão de Valores Mobiliários

II - definir:

b) a configuração de condições artificiais de demanda, oferta ou preço de valores mobiliários, ou de manipulação de preço; operações fraudulentas e práticas não equitativas na distribuição ou intermediação de valores;"

Haja vista a péssima redação da alínea em referência, não se vislumbra, pelo menos à primeira vista, uma alteração significativa no que se refere à delimitação de competências da CVM a respeito desses ilícitos do mercado de capitais.

Com efeito, o artigo 18, inciso II, alínea b, da lei 6.385/1976 repete as competências do órgão regulador estabelecidas no artigo 10, inciso VII, da antiga lei, apenas tentando explicar melhor o escrito anteriormente, utilizandose inclusive de expressões muito parecidas com as que foram colocadas no artigo $4^{\circ}$, inciso $\mathrm{V}$, da mesma lei que, por sua vez, é cópia fiel do artigo $2^{\circ}$ da Lei 4.728/1965.

Em que pese a nítida infelicidade da redação do artigo 18, inciso II, alínea b, da lei 6.385/1976, a CVM, com base exclusivamente nele, editou a Instrução 08, de 8 de outubro de 1979. Dispõe o ato normativo:

"I - É vedada aos administradores e acion istas de companhias abertas, aos intermediários e aos demais participantes do mercado de valores mobiliários, a criação de condições artificiais de demanda, oferta ou preço de valores mobiliários, a manipulação de preço, a realização de operações fraudulentas e o uso de práticas não eqüitativas."

Deste modo, é possível afirmar que a Instrução definiu quatro ilícitos distintos que podem ser cometidos no mercado de capitais, a saber: (i) a 
criação de condições artificiais de oferta, demanda e preço de valores mobiliários; (ii) manipulação de preços; (iii) operações fraudulentas e (iv) prática não eqüitativa.

A Instrução CVM nº 08/1979 define, ainda, em seu inciso II, os ilícitos acima citados, passíveis de punição por parte da CVM no âmbito do mercado de valores mobiliários, como segue:

"II - Para os efeitos desta Instrução conceitua-se como:

a) condições artificiais de demanda, oferta ou preço de valores mobiliários aquelas criadas em decorrência de negociações pelas quais seus participantes ou intermediários, por ação ou omissão dolosa provocarem, direta ou indiretamente, alterações no fluxo de ordens de compra ou venda de valores mobiliários;

b) manipulação de preços no mercado de valores mobiliários, a utilização de qualquer processo ou artifício destinado, direta ou indiretamente, a elevar, manter ou baixar a cotação de um valor mobiliário, induzindo, terceiros à sua compra e venda;

c) operação fraudulenta no mercado de valores mobiliários, aquela em que se utilize ardil ou artifício destinado a induzir ou manter terceiros em erro, com a finalidade de se obter vantagem ilícita de natureza patrimonial para as partes na operação, para o intermediário ou para terceiros;

d) prática não eqüitativa no mercado de valores mobiliários, aquela de que resulte, direta ou indiretamente, efetiva ou potencialidade, um tratamento para qualquer das partes, em negociações com valores mobiliários, que a coloque em uma indevida posição de desequilíbrio ou desigualdade em face dos demais participantes da operação."

Há de se ressaltar que o referido ato normativo é um dos mais criticados pelos juristas que se debruçam sobre a matéria, principalmente por ser excessivamente confuso e vago, gerando as mais diversas distorções por parte do operador do Direito.

A maior confusão que se pode citar diz respeito às alíneas a e b do inciso II, quando são definidos os ilícitos - supostamente diferentes - de criação de condições artificiais de oferta, demanda e preços e manipulação de preços.

Para tentar esclarecer a confusão acima citada, criada na edição da referida Instrução, recorrer-se-á à análise da manipulação de mercado no 
âmbito do Direito Penal, além de extrair elementos das previsões normativas dispostas no Direito Comparado sobre a matéria.

Neste momento, pretende-se apenas realizar uma análise de como dispõem as mais variadas leis sobre a manipulação de mercado de um modo geral. Aqui pouco importará se a prática é ou não considerada como crime pelo ordenamento que a tipificou. Isto porque, o que se pretende é a análise do ilícito em si.

Com efeito, o ilícito criminal ou administrativo pode ser entendido como sendo aquele que o Estado quis conferir punição maior ou menor, respectivamente, de acordo com uma conduta considerada pela sociedade como de maior ou menor gravidade.

Neste sentido,

"não há, em princípio, uma distinção de essência entre o ilícito civil, o penal e o administrativo; em todos eles existe o mesmo fundamento ético, constituído pela infração a um dever preexistente e pela imputação do resultado à consciência do agente. Assim, a ilicitude é uma só, embora as suas conseqüências, na esfera jurídica, possam ser diversas. (...) Em função da intensidade e da natureza do bem jurídico ofendido é que surgirão as distintas consequiências legais. (...) A distinção entre o ilíc ito administrativo e penal somente pode ser encontrada a partir de critérios meramente formais, tendo em vista as fontes legislativas e os órgãos encarregados da aplicação de sanções: no primeiro caso, os preceitos estão previstos em leis ou em normas regulamentares e são aplicados pela autoridade administrativa; já no segundo, os ilícitos estão previstos no Código Penal e legislação criminal extravagante e são julgados pelo Poder Judiciário." 36

Deste modo, não fará diferença, especificamente para esta análise, saber se determinado ente estatal quis punir o indivíduo na esfera penal - com maior força punitiva, incluindo penas de privação de liberdade - ou administrativa.

${ }^{36}$ EIZIRIK et alt., p. 519. 


\section{2. - Manipulação de Mercado no Direito Penal}

Em que pese a ampla discussão existente sobre a manipulação de mercado no âmbito legislativo e administrativo, sua tipificação como conduta criminosa só ocorreu em 2001, com a reforma promovida na Lei 6.385/1976 pela lei 10.303/2001.

Através da reforma, o legislador ordinário brasileiro mo dificou vários dispositivos que regiam o mercado de valores mobiliários e as sociedades anônimas. Uma das grandes inovações trazidas foi a inclusão dos artigos 27-C, 27-D e 27-E, na lei 6.385/1976, tipificando como crimes a manipulação de mercado, a negociação com informações privilegiadas (comumente chamada de insider trading) e o exercício irregular de cargo, profissão, atividade ou função.

Neste estudo, iremos abordar somente o ilícito contido no artigo 27-C, qual seja, a manipulação de mercado. Os outros - insider trading e exercício irregular de cargo, profissão, atividade ou função - não fazem parte de nossa análise, pelo fato de não estarem a princípio relacionados com os ilícitos considerados como objeto do trabalho.

Vale ressaltar que, apesar de o lícito de insider trading ter sido muitas vezes processado com base na Instrução 08/1979, mais especificamente no inciso I c/c o inciso II, d, (prática não eqüitativa), ele não será objeto de análise neste trabalho, conforme indicado no item 1 (Introdução) supra.

Com efeito, o artigo 27-C da Lei 6.385/1976 dispõe o seguinte:

\section{"Manipulação do Mercado}

Art. 27-C. Realizar operações simuladas ou executar outras manobras fraudulentas, com a finalidade de alterar artificialmente o regular funcionamento dos mercados de valores mobiliários em bolsa de valores, de mercadorias e de futuros, no mercado de balcão ou no mercado de balcão organizado, com o fim de obter vantagem indevida ou lucro, para si ou para outrem, ou causar dano a terceiros: 
Pena - reclusão, de 1 (um) a 8 (oito) anos, e multa de até 3 (três) vezes o montante da vantagem ilícita obtida em decorrência do crime."

Com a tipificação da manipulação de mercado como crime, visa o legislador a defender a processo de livre formação de preços, inerente a um mercado eficiente ${ }^{37}$, onde as cotações dos títulos são determinadas conforme a livre combinação entre os fatores oferta e demanda. Pretende também resguardar a credibilidade do mercado e a confiança, por parte dos investidores, em suas instituições. Vale dizer que, conforme visto no item 2.2 acima, tais valores são imprescindíveis para a existência de um mercado forte e desenvolvido.

É possível afirmar que são dois os núcleos do tipo penal que ora se comenta. São eles a realização (i) operações simuladas e (ii) de manobras fraudulentas.

Vale dizer, as expressões "operações simuladas" e "manobras fraudulentas" abrigam elementos normativos do tipo penal acima descrito, e necessitam, para sua caracterização, que o magistrado ultrapasse sua função de conhecimento para que produza um juízo de valor sobre a situação ${ }^{38}$.

Alguns autores afirmam que "operações simuladas nada mais são do que uma espécie do gênero manobras fraudulentas, como o próprio legislador dá a entender ao empregar o adjetivo outras (antes do substantivo manobras), $(\ldots)^{, 39}$ (grifos do autor)

\footnotetext{
${ }_{37}^{37}$ A esse propósito, ver Capítulo 2.

38 Damásio Evangelhista de Jesus explica, c itando Edmund Mezger, que "enquanto os elementos objetivos e subjetivos dizem respeito às partes integrantes do tipo penal fixadas pelo legislador descritivamente como determinados estados e processos corporais e anímicos, e, em consequiência, hão de ser verificados caso por caso pelo juiz, cognitivamente - nos elementos típicos normativos cuida-se de pressupostos do injusto típico que podem ser determinados tão-só mediante juízo de valor da situação de fato". (JESUS, Damásio Evangelhista de. Direito Penal: Parte Geral, $27^{\text {a }}$ Ed., São Paulo: Saraiva, p. 272-273)

${ }^{39}$ TORTIMA, José Carlos. Crimes Contra o Sistema Financeiro Nacional: Uma contribuição ao Estudo da Lei $\mathrm{n}^{\circ}$ 7.492/86. Rio de Janeiro: Lumen Iuris, 2002, p. 175.
} 
Entretanto, apesar de que a leitura do referido artigo transmite, à primeira vista, a impressão de se tratarem de institutos semelhantes, que fariam parte do mesmo gênero, o que se pretende tipificar com o referido texto normativo são dois institutos - simulação e fraude - há muito utilizados e estudados em outras áreas do Direito.

Trazendo tais lições para o âmbito da regulação do mercado de capitais, Modesto Carvalhosa e Nelson Eizirik ensinam:

"No primeiro caso - realizar operações simuladas - exige-se a presença da simulação, que consiste no difarce, no simulacro, no artifício ou fingimento na prática de um ato com a intenção de enganar, de mostrar como verdadeiro algo que é falso. ${ }^{40}$

Definem, ainda, o ato fraudulento - e, por conseguinte, manobra fraudulenta - como "aquele que consiste na violação de direitos de outra parte ou da lei, não segundo seu conteúdo material, mas segundo a mens legis ou a sententia da norma proibitiva; assim, aquele que frauda não necessariamente contradiz as palavras da lei, dando mesmo a impressão de que as observa, quando, na realidade, as infringe, indo contra o sentido que as ditou"41.

De acordo com o disposto no artigo 27-C, o crime de manipulação de mercado encerra um duplo elemento subjetivo, a saber, a (i) alteração do funcionamento regular dos mercados e a (ii) obtenção de uma vantagem ilícita para si ou para outrem.

Sobre a obtenção de vantagem ilícita, não resta dúvida. Qualquer ato ilícito provocado no mercado de capitais tem como fim alcançar uma vantagem - geralmente pecuniária - ao agente que o pratica, a ponto de Fausto Martin De Sanctis considerar tal previsão legislativa uma redundância, como segue:

\footnotetext{
${ }^{40}$ CARVAlHOSA, Modesto e EIZIRIK, Nelson. A Nova Lei das S/A. São Paulo: Saraiva, 2002, p. 536.

${ }^{41}$ Ibid., p. 537-538.
} 
"Essa última finalidade, creio, s.m.j., ser uma redundância do legislador, pois não seria possível cogitar de fraude sem o intuito de prejudicar terceiros com a obtenção de vantagem indevida",42.

Outro elemento importante na caracterização do crime ora analisado é a alteração do funcionamento regular dos mercados. Conforme o disposto no artigo 27-C, para a caracterização do crime de manipulação de mercado, o agente deve ter a alteração do funcionamento regular dos mercados como elemento mental que norteia sua conduta.

Segundo a doutrina, "alterar artificialmente o regular funcionamento dos mercados, significa criar condições artificiais de demanda ou de oferta e, assim, de preço para os títulos, mercadorias ou valores negociados em tais mercados. $^{43}$

Em que pese o fato de que o próprio artigo da lei, bem como parte da doutrina, considerar a alteração do funcionamento do mercado como elemento subjetivo, ou seja, a intenção que deve necessariamente ter o agente que se enquadra naquela conduta, é difícil supor que alguém pratique determinado ilícito com o objetivo de alterar o funcionamento regular do mercado.

Em geral, os investidores que manipulam o mercado almejam um benefício patrimonial para si ou para terceiros relacionados. Alterar o funcionamento regular do mercado acaba sendo conseqüência do ilícito, e não sua causa.

Por mais que o elemento subjetivo do tipo, conforme expõe a doutrina penalista, não seja constituído somente pela vontade do agente, mas também pela consciência de que sua atitude está produzindo aquele resultado indesejado pela lei, não há que se falar em alteração do funcionamento regular dos mercados como finalidade do agente que manipula o mercado.

\footnotetext{
${ }^{42}$ SANCTIS, Op. Cit., p. 101.

43 TORTIMA, Op. Cit., p. 176-177.
} 
Nesse sentido, analise-se o caso hipotético:

(i) um agente qualquer realiza determinada operação simulada ou manobra fraudulenta com o fim de obter vantagem ilícita para si ou para outrem;

(ii) a manobra, por sua proporção ou por circunstâncias a ela inerentes, é suscetível de alterar o funcionamento dos mercados;

(iii) essa alteração não é desejada especificamente pelo agente. A finalidade e, portanto, o dolo do agente é no sentido da obtenção da vantagem indevida.

Considerando os elementos deste caso hipotético, surge o questionamento: tal conduta não deve ser enquadrada como manipulação de mercado, apenas porque o agente não tinha o objetivo específico de alterar o seu funcionamento regular?

A resposta, evidentemente, é não. Deste modo, fica claro que não é necessário, para caracterização do tipo manipulação de mercado, que o agente queira a alteração do funcionamento do mercado, e sim que o ato por ele praticado seja capaz de alterá- $10^{44}$.

Ou seja, tal elemento deve existir no tipo penal. Muitas vezes conseguirse-á provar que o agente tinha a consciência de que por meio de seu artifício estaria alterando o funcionamento regular dos mercados. Porém, em virtude do acima exposto, não deve ser considerado como a finalidade da conduta do agente para que seja caracterizado o crime de manipulação do mercado.

Vale dizer também que o elemento "alteração do funcionamento regular dos mercados" já prevê o intuito de induzir terceiros à compra ou venda dos valores. Isto se dá, principalmente, porque tal indução é decorrente da própria alteração do funcionamento regular do mercado.

\footnotetext{
${ }^{44}$ A tipificação da manipulação de mercado no Direito Português segue expressamente esse sentido. Para melhor explicação, ver item 3.3 abaixo.
} 
Considerando que o preço de um determinado título geralmente revela as perspectivas que tem o mercado e seus participantes sobre o negócio que aquele valor representa, uma alteração artificial acaba sendo responsável por transmitir uma informação equivocada a quem não está ligado ao negócio em questão, ou quem possui no preço sua única ou principal fonte de informação sobre o título ${ }^{45}$.

Deste modo, no momento em que os investidores percebem um preço elevado, ou ascendente - mesmo que artificialmente, pois em geral o público investidor não tem conhecimento dessa artificialidade -, tendem a comprar aquele título, com objetivo de se aproveitar daquele movimento de alta. $\mathrm{O}$ inverso ocorre na manipulação do mercado para reduzir a cotação de um valor mobiliário.

Com efeito, provocar a compra ou venda de determinado valor mobiliário que tenha preço alterado por ilícito no mercado por investidores desavisados é uma forma clara de indução de terceiros a erro.

Ademais, a doutrina critica o dispositivo, com base no argumento de que ele seria uma mistura indiscriminada entre os três primeiros ilícitos administrativos definidos pela Instrução 08/1979, a saber a criação de condições artificiais de demanda, oferta e preço, a manipulação de preços e operações fraudulentas ${ }^{46}$.

Nesse sentido, vale dizer que o referido dispositivo se assemelha em significado ao inciso $\mathrm{V}$ do artigo $4^{\circ}$ da Lei 6.385/1976, incluído entre as finalidades da CVM, já citado acima, que é novamente transcrito para facilitar a análise:

"V - evitar ou coibir modalidades de fraude ou manipulação destinadas a criar condições artificiais de demanda, oferta ou preço dos valores mobiliários negociados no mercado;"

\footnotetext{
${ }^{45}$ Para explicação detalhada sobre essa função dos preços, ver item 3.2 acima.

${ }^{46}$ Neste sentido, CARVALHOSA e EIZIRIK, Op. Cit., p. 532.
} 
Sendo assim, é possível afirmar que a tipificação do crime pela lei se coaduna com os objetivos e finalidades expostas no artigo $4^{\circ}$, inciso $\mathrm{V}$, da Lei 6.385/1979, principalmente pelo fato que os dois definem a atitude do Estado na esfera criminal e administrativa - no sentido de evitar a ocorrência de operações fraudulentas ou simuladas que tenham por consequiência a alteração do funcionamento regular do mercado, através da criação de condições artificiais de demanda, oferta e preço no mercado de valores mobiliários.

\section{3 - Manipulação de mercado no Direito Comparado}

Com efeito, a previsão de sanções à prática de manipulação de mercado pode ser identificada em várias legislações no direito internacional.

No direito norte-americano, considerado por muitos como referência na disciplina do mercado de valores mobiliários, a matéria é tratada desde 1934, quando foi editado o Securities and Exchange Act of 1934. Dispõe a section 9 do referido ato ${ }^{47}$ o seguinte:

"Sec. 9. Manipulation of security prices

It shall be unlawful for any person, directly or indirectly, by the use of the mails or any means or instrumentality of interstate commerce, or of any facility of any national securities exchange, or for any member of a national securities exchange

(...)

(2) To effect, alone or with one or more other persons, a series of transactions in any security registered on a national securities exchange or in connection with any security-based swap agreement (as defined in section 206B of the Gramm-Leach-Bliley Act) with respect to such security creating actual or apparent active trading in such security, or raising or depressing the price of such security, for the purpose of inducing the purchase or sale of such security by others."

\footnotetext{
${ }^{47} \mathrm{O}$ dispositivo é muito extenso e a referência foi editada para que fosse mostrada apenas a conduta que mais se assemelha ao tipo penal equivalente estabelecido no Direito Brasileiro. Outros trechos da referida "section" serão citados ao longo deste trabalho.
} 
É possível depreender claramente do dispositivo acima que o legislador norte-americano estabeleceu certos requisitos e elementos para a tipificação da conduta de "manipulation of securities prices", o que seria equivalente ao nosso ilícito de manipulação de preços.

É conhecido o afã norte-americano por esclarecer, aos mínimos detalhes e minudências, cada tipo de conduta passível de punição no mercado. Por isso, a grande extensão da referida "section".

Para nós, ela revela, então, alguns exemplos de conduta que podem ser considerados "manipulation of prices", como a negociação repetida do mesmo título entre dois indivíduos, pelos mesmos preços, para criar uma falsa aparência de liquidez.

De qualquer forma, ficam claros dois elementos inerentes à manipulação de preços no Direito norte-americano. Seriam tais requisitos (i) a criação de uma falsa aparência de negociação ativa, ou seja, liquidez, ou de preços artificialmente aumentados ou diminuídos; e o (ii) o objetivo de induzir um terceiro à compra ou venda de valores mobiliários;

No Direito Português, o artigo Artigo 379. ${ }^{\circ}$ do Código do Mercado de Valores Mobiliários tipifica o crime de manipulação de mercado, como segue:

"Manipulação do mercado

1 - Quem divulgue informações falsas, incompletas, exageradas ou tendenciosas, realize operações de natureza fictícia ou execute outras práticas fraudulentas que sejam idóneas para alterar artificialmente o regular funcionamento do mercado de valores mobiliários ou de outros instrumentos financeiros é punido com prisão até três anos ou com pena de multa.

2 - Consideram-se idóneos para alterar artificialmente o regular funcionamento do mercado, nomeadamente, os actos que sejam susceptíveis de modificar as condições de formação dos preços, as condições normais da oferta ou da procura de valores mobiliários ou de outros instrumentos financeiros ou as condições normais de lançamento e de aceitação de uma oferta pública." 
Vale dizer, a legislação portuguesa, assim como a referida seção do Securities and Exchange Act norte-americano, prevêem a questão de divulgação de informações falsas, que a lei brasileira não prevê expressamente $^{48}$.

A despeito dessa questão, ficam claros, no artigo supracitado do Código que rege o mercado de valores mobiliários português, os mesmos requisitos previstos no artigo 27-C da lei $6.385 / 1976$ para a caracterização de manipulação de mercado.

Tais requisitos são (i) a utilização de simulação ou fraude no âmbito de operações realizadas no mercado de valores mobiliários; e (ii) que, através de tal procedimento simulado ou fraudulento, seja alterado o regular funcionamento dos mercados.

Vale ressaltar aqui que, como dito na nota 4, no item 3.2 acima, a legislação portuguesa não exige, para a caracterização do crime de manipulação de mercado, que o agente tenha intenção específica de alterar o funcionamento do mercado.

Desse modo

"não se exige que a conduta seja especificamente dirigida a produzir o efeito no mercado ou sequer que o produza mas apenas que seja susceptível de o produzir. O que é necessário demonstrar neste caso, não é, assim, que a actuação do agente se dirija à produção daquele efeito mas apenas que ele saiba que a sua conduta é susceptível de o produzir." 49

\footnotetext{
${ }^{48}$ Isso não quer dizer, entretanto, que tal prática seja permitida no ordenamento jurídico brasileiro. Mesmo não estando tipificada no artigo em análise, a divulgação de informações falsas é reprimida como manipulação de preços pela Comissão de Valores Mobiliários. A propósito, "2. No presente caso, os fatos apurados que revelam a tentativa de manipulação de preço das ações de emissão da Cosipa levam à conclusão de que o indiciado, no mínimo, queria tirar algum proveito com essa atitude. Conforme ficou comprovado, o Sr. Ciro Tourinho, que era acionista da Cosipa, de fato, simulou conversa no Fórum In vestShop, utilizando para isso dois pseudônimos, sendo um deles com dados fictícios, que confirmava, inclusive com base em fontes da CVM, que as ações seriam recompradas a um preço superior ao de mercado.". Processo Administrativo Sancionador TARJ2001/6226, julgado em 15.05.2003. Disponível em www.cvm.gov.br.

${ }^{49}$ BOLINA, Helena. A Manipulação de Mercado e o Abuso de Informação Privilegiada na nova Directiva sobre Abuso de Mercado (2003/6/CE). In Cadernos do Mercado de Valores Mobiliários, n. ${ }^{\circ}$ 18, Agosto de 2004, CMVM, Lisboa, p. 68.
} 
A Diretiva da Comissão Européia sobre Abuso de Mercado (2003/6/CE) anda no mesmo sentido. Com efeito, o documento apresenta definição que prescinde do elemento especial do ilícito de manipulação, qual seja, a intenção de manipular. Segundo a doutrina, tal preocupação por parte da Comissão Européia se deveu ao fato de que poucos processos resultavam em condenação, dada a dificuldade da prova sobre tal elemento. ${ }^{50}$

Há, ainda, a indução de terceiros a compra ou venda dos valores que, apesar de não colocada expressamente pelo legislador português, decorre, como visto acima ${ }^{51}$, da alteração do funcionamento regular dos mercados.

O Código português revela, ainda, quais seriam os atos capazes de alterar o funcionamento regular dos mercados e, portanto, suscetíveis de enquadramento do crime de manipulação, quais sejam, aqueles que alterem as condições normais de oferta de formação dos preços.

Vê-se, claramente, que os atos ditados pelo legislador português se assemelham aos considerados pelo legislador brasileiro como necessários à caracterização da manipulação de mercado.

Ou seja, o legislador português define como crime a manipulação de mercado, à semelhança do que fez o brasileiro, e ainda explica, no item seguinte, quais seriam, genericamente, os atos suscetíveis de enquadramento no referido ilícito criminal.

Com efeito,

"o crime de manipulação de mercado realiza-se quando se verifiquem uma das condutas enunciadas, seguidamente:

1. divulgação de informações falsas, incompletas, exageradas ou tendenciosas;

2. realização de operações de natureza fictícia;

3. execução de práticas fraudulentas idôneas para alterar artificialmente o regular funcionamento do mercado, nomeadamente:

a) praticar actos capazes de influenciar e modificar as condições de formação dos preços;

\footnotetext{
${ }^{50}$ A respeito, ver BOLINA, Op. Cit., p. 68.

${ }^{51}$ Ver item 3.2.
} 
b) praticar actos capazes de influenciar e modificar as condições normais da oferta e da procura;

c) praticar actos capazes de influenciar e modificar as condições normais de lançamento e aceitação de uma oferta pública."

Tal análise reforça a idéia defendida acima de que o ilícito em si é manipulação de mercado, que possui, dentre um de seus elementos, a criação de condições artificiais de demanda, oferta e de preços no mercado de valores mobiliários.

Tendo sido enumerados os elementos caracterizadores do crime de manipulação de mercado, deve-se retornar à análise dos ilícitos dispostos na Instrução CVM n n $^{\text {0 }}$ (1979, para assim tentarmos sistematizar o ilícito administrativo em tela.

\section{4 - Condições artificiais de demanda, oferta e preço e manipulação de preços. Tentativa de sistematização dos ilícitos analisados.}

Para uma análise mais detalhada dos ilícitos definidos nas alíneas a e b da Instrução 08/1979, é preciso que se tente extrair do texto normativo os requisitos que teriam sido apontados pela norma como necessários para a caracterização da infração administrativa.

Conforme definido pelo ato normativo que ora se comenta, a criação de condições artificiais de demanda, oferta e preço de valores mobiliários pode ser definida como "aquelas criadas em decorrência de negociações pelas quais seus participantes ou intermediários, por ação ou omissão dolosa provocarem, direta ou indiretamente, alterações no fluxo de ordens de compra ou venda de valores mobiliários;"

Com base no disposto acima, é possível afirmar que os elementos que caracterizam o ilícito são (i) uma ação ou omissão dolosa dos participantes de uma negociação de valores mobiliários e, como conseqüência de tal 
negociação, a (ii) alteração no fluxo de ordens de compra ou venda de valores mobiliários;

Já a manipulação de preços pode ser definida, conforme inciso II, (b), da Instrução 08/1979, como “a utilização de qualquer processo ou artifício destinado, direta ou indiretamente, a elevar, manter ou baixar a cotação de um valor mobiliário, induzindo, terceiros à sua compra e venda;"

Pelo texto normativo, é possível estabelecer os elementos desse ilícito como (i) utilização de um artifício qualquer; o (ii) objetivo de elevar, manter ou baixar a cotação de um valor mobiliário qualquer. Também chamado de cotação falsa, ou enganosa; além disso, tal alteração na cotação deve (iii) induzir terceiros à compra ou venda de determinado valor mobiliário.

A doutrina tenta identificar os elementos da caracterização do ilícito de manipulação de preços. A este respeito, pode se afirmar que "artifícios integram a categoria dos meios fraudulentos, caracterizando-se pois como instrumentos de engano ou erro."52

Do mesmo modo, é possível afirmar que "a cotação de um título no mercado deve resultar sempre do jogo contingente da oferta e da procura, sendo, assim, reputada uma cotação legítima, cabendo considerá-la falsa se as condições de mercado, que a determinaram, não correspondem ao curso normal da oferta e da procura. São 'condições artificiais de demanda, oferta ou preço', e portanto, ilegítimas." 5354

A jurisprudência da CVM exige, para comprovação da indução de terceiros à compra ou venda do valor mobiliários e, por conseguinte, a caracterização de manipulação de preços, que se verifique qual foi $o$

\footnotetext{
52 LEÃES, Luiz Gastão Paes de Barros, Pareceres. São Paulo: Singular, 2004, vol. 2, p. 1030.

${ }_{54}^{5}$ Ibid., p. 1031-1032.

${ }^{54}$ Vê-se claramente com a leitura da referida passagem que o ilustre jurista também entende que a criação de condições artificiais de demanda, oferta e preço de valores mobiliários é um elemento do ilícito de manipulação de preços (ou de mercado). Com efeito, é isso o que este trabalho pretende demonstrar.
} 
comportamento dos títulos após o período em que se considera que tenha havido a manipulação.

Nesse sentido,

"133. A falta de comprovação da queda dos "preços manipulados" posteriormente à operação que teria lesado o Fundo Maxyield não permitem concluir que o preço tenha sido manipulado e não, apenas, subido. Adicionalmente, como o Investidor Utilities não participou de qualquer outra operação com essas ações, para que ele tivesse "manipulado preços", deveria haver prova da ligação entre o Investidor Utilities e o administrador do Maxima Fund e do Fundo Maxyield. ${ }^{, 55} 56$

Em que pese o fato de que, mediante sua competência normativa, o ente estatal regulador do mercado se propôs a demarcar diferenças entre as condutas apontadas nos itens (a) e (b) do inciso II da Instrução CVM nº 08/1979, é possível afirmar que tais requisitos apontam para o mesmo tipo delituoso.

Entretanto, tendo em vista que a lei - aparentemente - e Instrução 08/1979 estabeleceram distinções entre os dois tipos, a doutrina e jurisprudência tentam confirmar o disposto no ato normativo, dissertando sobre as diferenças entre as duas condutas ilícitas.

Com efeito, Nelson Eizirik afirma que a

"criação de condições artificiais, porém, distingue-se da manipulação por abranger um universo mais amplo de delitos; enquanto a manipulação refere-se apenas aos preços, melhor dizendo, às cotações dos valores mobiliários, a criação de condições artificiais pode também ocorrer com relação à oferta ou demanda de valores mobiliários. ${ }^{, 57}$ (EIZIRIK ET alt, p. 530)

\footnotetext{
${ }^{55}$ Processo Administrativo Sancionador CVM no 29/2003, julgado em 16.01.2007. Relator: Diretor Pedro Oliva Marcilio de Sousa. Disponível em www.cvm.gov.br.

${ }^{56}$ No mesmo sentido, Processo Administrativo Sancionador No RJ2005/7389, julgado em 10.10.2006. Relator: Marcelo Fernandez Trindade.

${ }^{57}$ EIZIRIK el atl., Op. Cit., p. 530.
} 
O jurista cita, ainda, como exemplo de um ato que constituiria apenas o ilícito da alínea (a) do inciso II da Instrução CVM nº 08/1979 - criação de condições artificiais de demanda, oferta e preço - a hipótese abaixo:

"se duas instituições financeiras, desejando criar uma 'aparência' de liquidez para determinada ação, passam a negociá-la, entre si, aumentando o volume de transações, sem que sua cotação seja alterada, caracteriza-se a criação de condições artificiais, mas não a manipulação de preços, na esfera do direito administrativo sancionador." ${ }^{58}$

Com efeito, a negociação entre partes previamente pactuadas, mediante a troca sistemática da titularidade dos valores mobiliários entre ambos os participantes da operação, é prática ilícita objeto de condenações em diversos processos administrativos sancionadores no âmbito da CVM.

Veja-se a este respeito:

"27. Houve, portanto, criação de condições artificiais de demanda, na medida em que, como informam os próprios defendentes, partiram deles próprios as ordens que representaram $99 \%$ do volume financeiro negociado, produzindo assim uma falsa idéia de liquidez, que no entanto não guardava qualquer relação com o mercado real dos papéis da SERGEN S/A. Assim, é induvidoso que a atuação dos acusados alterou o fluxo natural de ordens de compra e venda dos papéis. ${ }^{~} 59$

Há quem sustente que a negociação previamente combinada entre duas partes para criar uma aparência de liquidez, sem alterar a cotação dos títulos objeto do conluio, seja caracterizada como criação de condições artificiais.

Entretanto, vale dizer que a promoção de uma aparência de liquidez não produz outro efeito senão o de elevar a cotação de um valor mobiliário.

Isto porque, um título que tenha mais liquidez é mais atrativo ao investidor, devido ao fato de que ele pode se desfazer do ativo com mais facilidade. Com efeito, um aumento de liquidez de determinado título faz com que um número maior de participantes do mercado deseje proceder à sua

\footnotetext{
58 Ibid., p. 530.

${ }^{59}$ Processo Administrativo Sancionador CVM n ${ }^{\circ}$ RJ2004/0210, julgado em 29.03.2006. Relator: Diretor Sérgio Weguelin.
} 
compra, aumentando a "naturalmente" demanda por esses títulos e, por conseguinte, seu preço.

A este propósito, vale dizer que tal conduta - negociação previamente combinada com o intuito de "criar" liquidez - está tipificada como "manipulation of securities prices", na "section" 9 do Securities and Exchange Act norte americano, como segue:

"It shall be unlawful for any person, directly or indirectly, by the use of the mails or any means or instrumentality of interstate commerce, or of any facility of any national securities exchange, or for any member of a national securities exchange

(1) For the purpose of creating a false or misleading appearance of active trading in any security registered on a national securities exchange, or a false or misleading appearance with respect to the market for any such security, (A) to effect any transaction in such security which involves no change in the beneficial ownership thereof, or (B) to enter an order or orders for the purchase of such security with the knowledge that an order or orders of substantially the same size, at substantially the same time, and at substantially the same price, for the sale of any such security, has been or will be entered by or for the same or different parties, or (C) to enter any order or orders for the sale of any such security with the knowledge that an order or orders of substantially the same size, at substantially the same time, and at substantially the same price, for the purchase of such security, has been or will be entered by or for the same or different parties."

Deste modo, fica claro que, no âmbito do direito norte-americano não há distinção entre os tipos ilícitos os quais se pretende diferenciar aqui no Direito Brasileiro.

A ex-Diretora da Comissão de Valores Mobiliários, Dra. Norma Parente, afirma em voto dado no Processo Administrativo Sancionador CVM RJ2004_2132 ${ }^{60}$, que a ocorrência da efetiva compra das ações por parte do agente afasta o ilícito de criação de condições artificiais de demanda, aproximando-se da manipulação de preços.

Ocorre que, nos casos acima citados, houve ordens efetivas de compra e venda de valores mobiliários. Só que estas ordens de compra e venda eram

\footnotetext{
${ }^{60}$ Processo julgado em 19.01.2005. Disponível em www.cvm.gov.br.
} 
previamente pactuadas entre os agentes com o objetivo de indefinidamente alterar entre eles a propriedade dos valores mobiliários e gerar volumes maiores de transação, induzindo, assim, terceiros à compra dos títulos e manipulando o mercado.

Apesar de tentarem os juristas e estudiosos do tema estabelecer diferenças entre a criação de condições artificiais e a manipulação dos preços, não há, nos dispositivos sobre os quais se comenta, nenhuma expressão ou elemento que confirme ou de respaldo às diferenças apontadas.

Em que pese a aparente distinção entre os ilícitos acima apontados, quais sejam, a criação de condições artificiais de demanda, oferta e preço, e a manipulação de preços, a própria doutrina afirma que "a criação de condições artificiais de preço não se distingue ontologicamente da manipulação, (...)" e que "nos dois casos o que o agente visa é a alteração do livre jogo de oferta e procura dos valores mobiliários" ${ }^{\prime}$.

Nesse sentido, por mais que se possa afirmar, à primeira vista, que a lei 6.385/1976 conferiu à CVM poder para definir dois ilícitos diferentes, uma leitura mais atenta do referido dispositivo pode trazer uma idéia diferente da que geralmente é defendida.

Vale repetir o artigo 18, II, (b) da referida lei:

“Art. 18. Compete à Comissão de Valores Mobiliários II - definir:

b) a configuração de condições artificiais de demanda, oferta ou preço de valores mobiliários, ou de manipulação de preço; operações fraudulentas e práticas não equitativas na distribuição ou intermediação de valores;"

A primeira parte da referida alínea começa com a expressão "a configuração de condições artificiais" e termina em "manipulação de preço", e logo após o legislador colocou o sinal gramatical do ponto e vírgula.

${ }^{61}$ EIZIRIK ET ALT., Op. Cit., p. 529. 
Levando em conta a noção de que a figura do ponto e vírgula, amplamente usada em nossa linguagem, tem como objetivo separar idéias diferentes entre si, fica claro que o legislador pretendeu juntar as duas expressões dentro de um mesmo conceito.

Tal idéia fica mais clara quando o legislador inclui na alínea a preposição “ou” entre criação de condições artificiais e manipulação de preço, querendo assim demonstrar que se tratam de variações do mesmo ilícito, qual seja, a manipulação de mercado.

$\mathrm{Na}$ frase seguinte, dentro da mesma alínea, o legislador utiliza a preposição "e" entre operações fraudulentas e prática não eqüitativa, pretendendo informar tratar-se de dois ilícitos diferentes.

Vale dizer, neste momento, que é difícil supor que haja um tipo - penal ou administrativo, o que se mostra indiferente para essa análise- proibitivo em relação à manipulação de mercado, e outro que cuide só da manipulação de preços.

Com efeito, quem manipula preços está manipulando o mercado, e viceversa, já o preço ou cotação de um título nada mais é que o valor que o mercado - enquanto local onde as forças de oferta e demanda se encontram confere àquele título que está em negociação.

Além disso, como visto acima, a "criação de condições artificiais de demanda, oferta e preço" nada mais é do que um elemento que caracteriza a manipulação de mercado, tal como descrita no tipo penal analisado no item 4.3 supra.

É possível afirmar, ainda, que não há diferença semântica alguma entre a criação de condições artificiais de preço - tipo contido na alínea (a) da Instrução CVM 08/1979 - e a manipulação de preços, visto que manipular o preço de algum título é nada mais, nada menos, do que produzir uma variação artificial na sua condição de preço. 
Deste modo, fica claro que os três tipos acima citados - manipulação de mercado, criação de condições artificiais de demanda, oferta e preço e manipulação de preços - se referem à mesma conduta praticada no âmbito do mercado de valores mobiliários, aqui chamada de manipulação de mercado. Em última análise, os três ilícitos possuem os mesmos três requisitos.

São eles:

(i) a realização de operações simuladas ou fraudulentas, consistentes na utilização de artifícios ou processos;

(ii) que a realização de tais operações seja capaz de provocar ou que provoque a alteração do funcionamento regular do mercado, através da criação de condições artificiais de demanda ou preço, induzindo, desta forma, terceiros à compra ou venda dos valores mobiliários;

(iii) e que tenham por fim obter uma vantagem indevida ou ilícita ao agente ou a terceiros relacionados.

\section{5 - Outros ilícitos previstos na Instrução CVM no 08/1979. Operações fraudulentas e prática não-eqüitativa}

A Instrução CVM n ${ }^{\circ}$ 08/1979 define, ainda, outros dois ilícitos que passíveis de sanção no âmbito do Mercado de Valores Mobiliários. São eles a realização de operações fraudulentas e a prática não equiitativa.

\subsection{1 - Operações Fraudulentas}

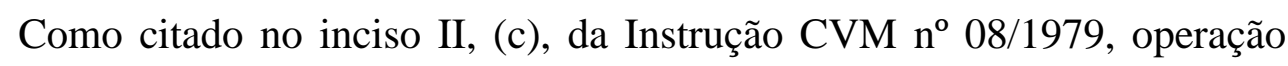
fraudulenta pode ser entendida como "aquela em que se utilize ardil ou artifício destinado a induzir ou manter terceiros em erro, com a finalidade de se obter vantagem ilícita de natureza patrimonial para as partes na operação, para o intermediário ou para terceiros;" 
A tipificação do ilícito administrativo parte do princípio que a fraude, bem como sua capacidade de causar prejuízos enormes ao público investidor, é perversa e destrutiva ao mercado, por afetar sua credibilidade e a confiança que nele devem depositar seus participantes.

É possível estabelecer os requisitos dispostos na Instrução necessários à caracterização do ilícito. São eles (i) a utilização de ardil ou artifício; (ii) a indução de terceiros a erro; e (iii) a obtenção de vantagem ilícita de natureza patrimonial.

Como visto no item 4.3 acima, a utilização de manobras fraudulentas constitui um elemento normativo do tipo penal "manipulação de mercado", disposto no artigo 27-C da Lei 6.385/1976.

Não há razão para supor que a fraude disposta na "manobra fraudulenta" prevista na Lei penal é diversa da fraude que se propõe definir a CVM por meio da Instrução 08/1979, em seu inciso II, (c).

Com efeito, "fraude, expressão da qual deriva o adjetivo fraudulenta, é o elemento objetivo do tipo do estelionato, significando o emprego de artifício ardiloso para induzir ou manter alguém em erro"62

Qual seria então a intenção do legislador ao conferir à CVM o poder para definir o que seriam operações fraudulentas?

Vale ressaltar que a Lei 6.385/1979 prevê expressamente, em seu artigo 18, II, (b), a competência da autarquia para a definição do ilícito que ora se comenta.

Conforme demonstrado nos itens acima, a criação de condições artificiais de demanda, oferta e preço e a manipulação de preços, bem como o crime de manipulação de mercado, admitem o uso de manobra ou meio fraudulento.

\footnotetext{
${ }^{62}$ TORTIMA, Op. Cit. 177.
} 
Fica claro, então, que o legislador pretendeu estabelecer, com a definição de operação fraudulenta, um tipo de operação em que se utilize a fraude, mas que não se altere o funcionamento regular dos mercados. Onde não se crie condições artificiais de oferta, demanda ou de preço.

Deste modo, a operação fraudulenta definida no inciso II, (c), da Instrução CVM nº 08/1979 pode ser entendida como qualquer outra manobra ou processo que tenha por objetivo proporcionar ao agente ou terceiro relacionado determinado benefício patrimonial. E que, nesta manobra, se induza terceiros a algum tipo de erro.

Sendo assim, é possível afirmar que o tipo administrativo operação fradulenta é subsidiário ao tipo de manipulação de mercado. Ou seja, quando houver qualquer manobra fraudulenta que não se encaixe na tipificação administrativa de criação de condições artificiais de demanda, oferta e preço (e a manipulação de preços), estar-se-á diante de uma operação passível de punição pela autoridade reguladora do mercado de capitais através do disposto no inciso II, (c), do referido ato normativo.

Tal opinião é compartilhada por Nelson Eizirik, como segue:

"O conceito de operação fraudulenta, porém, é de exemplificação difícil, senão impossível, constituindo atualmente, à semelhança do crime de estelionato, uma espécie de 'arma de reserva', na expressão de Nilo Batista, empregável apenas quando outras normas que reprimem diretamente determinada conduta não possam ser aplicadas., ${ }^{63}$

No âmbito de decisões em Processos Administrativos Sancionadores da Comissão de Valores Mobiliários ${ }^{64}$, vejam se as conclusões abaixo:

“41. Inicialmente, tendo em vista os fatos acima narrados e a ausência de elementos nos presentes autos que possam sustentar o contrário, entendo que resta caracterizada a prática, por Raimundo Nonato Diniz Rodrigues, de operação fraudulenta, nos termos dos incisos I e II, "c" da Instrução 08/79, com ações

\footnotetext{
${ }^{63}$ EIZIRIK, Nelson. Aspectos modernos do Direito Societário. Rio de Janeiro: Renovar. 1992, p. 188.

${ }^{64}$ A íntegra das decisões está disponível em www.cvm.gov.br.
} 
pertencentes ao Município de Formoso do Araguaia/TO, por ter ele se valido de procuração pública lavrada com documentação falsa conforme demonstrado." 65

"21. A fraude ficou induvidosamente comprovada, por razões óbvias, nas operações envolvendo ações pertencentes a três pessoas já falecidas - Ary Kefury, Valfrido Coimbra Grubert e Osmar Demeneck. Além disto, também na alienação de ações de propriedade de Namiyo Tanabe, e na tentativa de alienação de ações de Indústria e Comércio Martin Ltda., a Comissão de Inquérito conseguiu provar a ocorrência de fraude, no primeiro caso pela falsificação de instrumento de mandato, e no segundo pela falsa atribuição a Débora Gomes Capucci da qualidade de representante legal da empresa titular das ações. ${ }^{, 66}$

"A alegada fraude foi viabilizada mediante o uso de documentação falsa (fls. 32/33), incluindo procuração lavrada por instrumento público (fls. 34), o que possibilitou aos acusados se apoderarem de recursos de outra pessoa., ${ }^{, 67}$

Desta forma, é possível afirmar que

"a jurisprudência da CVM identifica como ardilosas ou artificiosas, fundamentalmente, as condutas de prestação de declarações falsas ou utilização de documentos forjados ? tais como procurações, cédulas de identidade, fichas cadastrais, notas de negociação, e autorizações judiciais"

\subsection{2 - Prática não eqüitativa}

Como visto no item 4.1 acima, desde a edição da lei 4.728/1965, o legislador incluiu, entre as finalidades do órgão regulador do mercado de capitais - à época o Conselho Monetário Nacional -, o incentivo à observância de práticas comerciais eqüitativas na distribuição e intermediação de valores.

\footnotetext{
${ }^{65}$ Processo Administrativo Sancionador CVM No SP2004-0197, julgado em 12.01.2006. Relator: Pedro Oliva Marcilio de Sousa.

${ }^{66}$ Processo Administrativo Sancionador CVM no 16/2002, julgado em 10.10.2006. Relator: Marcelo Fernandez Trindade. Disponível em www.cvm.gov.br.

${ }^{67}$ Processo Administrativo Sancionador CVM TA-SP2004/0113, julgado em 09.12.2004. Relator: Wladimir Castelo Branco Castro. Disponível em www.cvm.gov.br.

${ }^{68}$ TRINDADE, Marcelo Fernandez. Parecer ainda não publicado de 25.02.2008.
} 
A lei $6.385 / 1976$ repetiu tal finalidade em seu artigo $4^{\circ}$, e conferiu poderes à recém criada $\mathrm{CVM}$ para definir o que seria a prática que contrariaria aquele mandamento legal.

Seguindo tal orientação, a Instrução CVM no 08/1979 definiu, em seu inciso II, (d), a prática não eqüitativa como "aquela de que resulte, direta ou indiretamente, efetiva ou potencialidade, um tratamento para qualquer das partes, em negociações com valores mobiliários, que a coloque em uma indevida posição de desequilíbrio ou desigualdade em face dos demais participantes da operação."

A vedação à prática não equitativa também guarda nítida correlação com a defesa da credibilidade do mercado, na medida em que visa a coibir que determinados agentes, especialmente intermediários financeiros, utilizemse da posição de confiança que possuem em relação ao investidor que representam para auferir algum benefício patrimonial.

Fica claro, então, que a norma tem por objetivo evitar a ocorrência de conflitos de interesses, geralmente entre o investidor e os intermediários financeiros que atuam no mercado de valores mobiliários.

Parte da doutrina critica o dispositivo pelo fato de ele ter trazido uma idéia de equity (igualdade) do Direito norte-americano, fundado na Common Law, para o Direito Brasileiro, inspirado pelos princípios da Civil Law ${ }^{69}$.

Além disso, vale dizer que a referida alínea guarda uma incoerência em relação com o texto legal que a legitima.

O artigo 18, II, (b), que serviu de base para a edição da Instrução CVM $n^{\circ}$ 08/1979, prevê a competência da CVM para definir "práticas não equitativas na distribuição ou intermediação de valores".

Apesar de tal previsão específica, o ilícito definido no inciso II, (d), acima, prevê que as práticas não eqüitativas sejam cometidas em negociações 
com valores mobiliários, abrangendo conduta diversa daquela que foi prevista na lei 6.385/1976 para a ocorrência de tal ilícito.

Com efeito, a distribuição, a intermediação e a negociação de valores mobiliários são atividades que, apesar de guardarem uma relação harmoniosa, não se confundem entre si.

Sendo assim, é possível afirmar que o texto normativo ditado pela autarquia ampliou o ilícito para a atividade de negociação com valores mobiliários, coisa que a lei não tinha feito.

A despeito das questões acima elencadas, é possível extrair do texto normativo em análise os requisitos inerentes à caracterização da ocorrência de prática não eqüitativa no âmbito do mercado de valores mobiliários. São eles (i) uma ação ou omissão dolosa do agente, e que tal ação ou omissão (ii) provoque um desequilíbrio entre as partes de uma operação.

Com efeito, "a configuração do ilícito exige que a ação ou omissão dolosa dos acusados provoque como resultado uma efetiva posição de desequilíbrio para uma das partes na realização da operação." ${ }^{70}$

Vale dizer, ainda, conforme o disposto no texto legal e também na Instrução CVM 08/1979, que essa situação de desequilíbrio deve se dar entre participantes de uma operação específica, e não do mercado como um todo.

Outra crítica que se pode fazer é que o tipo definido é demasiado aberto e que, se sua aplicação fosse levada a extremos,

"seria desnecessária a existênci de outras regras sancionatórias para regular o funcionamento do mercado de capitais e das relações entre administradores e acionistas. Bastaria está única norma para que restassem proibidas todas as práticas que resultassem numa relação desequilibrada para uma das partes envolvidas -

\footnotetext{
${ }^{69}$ Nesse sentido, CASTELLAR, João Carlos, Insider Trading e os Novos Crimes Corporativos: uso indevido de informação privilegiada, manipulação de mercado e exercício irregular de cargo, profissão, atividade ou função. Rio de Janeiro: Lumen Iuris, 2008, p. 62.

${ }^{70}$ WALD, Alexandre de M. Uso de Prática Não-Eqüitativa. Inexistência: Memorial apresentado ao Conselho de Recursos do Sistema Financeiro Nacional. Revista de Direito Bancário, do Mercado de Capitais e da Arbitragem. São Paulo: Revista dos Tribunais, nº 9, jul-set/2000, p. 286.
} 
práticas não eqüitativas - que todos os casos hipotéticos estariam abrangidos, tornando-se despicienda aquela série de proibições legais." ${ }^{71}$

A propósito, leia-se trecho de voto proferido em julgamento datado de 03.07.2007, do ex-Diretor da CVM, Dr. Pedro Oliva Marcilio de Sousa, que segue:

“(...) a jurisprudência da CVM tem exigido a presença dos seguintes elementos, para que a acusação por prática não eqüitativa se justifique: (i) negociação no âmbito do mercado de valores mobiliários; (ii) tratamento que coloque qualquer das partes da operação em uma indevida posição de desequilíbrio ou desigualdade em face dos demais; (iii) dolo específico de auferir proveito da situação; e (iv) ocorrência de resultado, que pode ser direto ou indireto, consistente no desequilíbrio para uma das partes." ${ }^{, 72}$

A despeito do requisito (i) citado no trecho acima, que menciona a negociação no mercado de valores mobiliários - tal previsão contraria, como visto acima, o disposto no artigo 18, II, b, da Lei 6.385/1976 -, ficam claros, assim, os requisitos para a caracterização da prática não eqüitativa, assim como disposto na Instrução CVM nº 08/1979.

${ }^{71}$ CASTELLAR, Op. Cit., p. 64.

${ }^{72}$ Processo Administrativo Sancionador CVM nº 28/2005. Disponível em www.cvm.gov.br. 


\section{Capítulo 4 - Conclusão}

Há um dito popular que ensina que quanto mais se pesquisa, se estuda um determinado tema, e quanto mais se pensa conhecê-lo, mais se descobre, na verdade que pouco ou quase nada se sabe sobre ele.

É essa a impressão que, ao fim deste trabalho, se tem sobre o estudo dos ilícitos no Mercado de Valores Mobiliários. Com efeito, o tema é extenso e envolve uma infinidade de questões de grande complexidade.

A primeira conclusão que se pode estabelecer é que a atividade regulatória do mercado deve seguir os preceitos considerados por uma sociedade como relevantes para o desenvolvimento daquela atividade, e que, descobrindo, tais princípios e valores, podemos proceder a uma melhor análise dos melhores caminhos para a regulação.

É possível afirmar, ainda, que existem três princípios e valores determinantes na atuação do regulador do mercado de valores mobiliários, a saber, a eficiência, a informação e a proteção aos investidores, especialmente àqueles que não possuem condições de formar um juízo adequado sobre suas opções de investimento.

Por todo o exposto, fica claro ainda que, por mais que tenha a Instrução CVM nº 08/1979 definido, entre ilícitos diferentes, a criação de condições artificiais de demanda, oferta e preço e a manipulação de preços, tais infrações guardam grande similaridade, de forma que não se justifica ter o ente regulador, no exercício de sua função normativa, separado dois ilícitos, quando, na verdade, um é elemento que caracteriza do outro.

Ademais, vê-se claramente que o tipo operações fraudulentas prevê uma tipificação subsidiária em relação ao tipo de manipulação, na medida em que prevê todos os seus outros requisitos, à exceção da alteração do funcionamento regular dos mercados. 
Vale dizer, ainda, que o tipo de prática não eqüitativa revela uma proteção ao conflito de interesses e, em que pese o fato de ser muito amplo e sujeito a várias críticas, é de extrema importância no âmbito da regulação do Mercado de Valores Mobiliários.

De qualquer forma, a grande vitória que se pode afirmar ao final desse período foi a de despertar e aumentar o interesse - pelo menos pessoal - sobre o tema.

Espera-se que mais reflexões como essa sejam feitas a partir da legislação e de outros textos normativos, que realmente se volte olhares para a questão porque o debate é sempre a melhor saída, a melhor forma de construirmos um Direito mais justo e que reflita com melhor propriedade os anseios e aspirações da sociedade. 


\section{Bibliografia}

AMENDOLARA, Leslie. Fundamentos e Objetivos da Regulamentação do Sistema de Informação de Sociedades que fazem Ofertas Públicas. In: VII Congreso Argentino de Derecho Societario y III Congresso Iberoamericano de Derecho Societario y de la Empresa. La Sociedad Comercial ante El tercer milênio, Buenos Aires.

ARAGÃO, Alexandre dos Santos, O Conceito Jurídico de Regulação da Economia. Revista de Direito Mercantil, Industrial, Econômico e Financeiro. São Paulo: Malheiros Editores, n. 122, abr-jun/2001.

BOLINA, Helena. A Manipulação de Mercado e o Abuso de Informação Privilegiada na nova Directiva sobre Abuso de Mercado (2003/6/CE). In Cadernos do Mercado de Valores Mobiliários, n. ${ }^{\circ}$ 18, Agosto de 2004, CMVM, Lisboa.

CARVALHOSA, Modesto e EIZIRIK, Nelson. A Nova Lei das S/A. São Paulo: Saraiva, 2002.

CASTELLAR, João Carlos, Insider Trading e os Novos Crimes Corporativos: uso indevido de informação privilegiada, manipulação de mercado e exercício irregular de cargo, profissão, atividade ou função. Rio de Janeiro: Lumen Iuris, 2008.

CHEDIAK, Julian Fonseca Peña, A Reforma do Mercado de Valores Mobiliários, in: LOBO, Jorge, Reforma da Lei das Sociedades Anônimas: Inovações e Questões Controvertidas da Lei no 10.303, de 31.10.2001. Rio de Janeiro: Forense, 2002.

EIZIRIK, Nelson et atl. Mercado de Capitais Regime Jurídico. $2^{\mathrm{a}}$ Ed., Rio de Janeiro: Renovar, 2008.

EIZIRIK, Nelson. Regulação e Auto-regulação do mercado de valores mobiliários. Revista de Direito Mercantil, Industrial, Econômico e Financeiro. São Paulo: Malheiros Editores, n. 48, out-dez/1982.

Renovar. 1992, 236p.

Aspectos modernos do Direito Societário. Rio de Janeiro:

FERREIRA, Eduardo Paz, A informação no Mercado de Valores Mobiliários, in: Direito dos Valores Mobiliários. Coimbra: Coimbra Editora, 2001. 
JESUS, Damásio Evangelhista de. Direito Penal: Parte Geral, $27^{\mathrm{a}}$ Ed., São Paulo: Saraiva, 2003, 750p.

LEÃES, Luiz Gastão Paes de Barros, Pareceres. São Paulo: Singular, 2004.

MANKIW, N. Gregory. Introdução à Economia . [tradução Allan Vidigal Hastings], $3^{\text {a }}$ Ed., São Paulo: Pioneira Thomson Learning, 2005, 852p.

MOSQUERA, Roberto Quiroga. Os Princípios Informadores do Direito do Mercado Financeiro e de Capitais. In: MOSQUERA, Roberto Quiroga (Org.). Aspectos Atuais do Direito do Mercado Financeiro e de Capitais. São Paulo: Dialética, 1999.

PARENTE, Norma. A Regulação e o desenvolvimento do Mercado de Capitais. Revista de Direito Bancário, do Mercado de Capitais e da Arbitragem. São Paulo: Revista dos Tribunais, n. 18, out-dez/2002.

PEREIRA, José Nunes. O Novo Código dos Valores Mobiliários e a Protecção dos Investidores, in Cadernos do Mercado de Valores Mobiliários, n. ${ }^{\circ}$, Lisboa, 2000.

PINTO, Frederico Costa. O Direito de Informar e os Crimes de Mercado. Cadernos do Mercado de Valores Mobiliários , n. ${ }^{\circ}$ 2, 1. ${ }^{\circ}$ semestre de 1998, CMVM, Lisboa.

REIS, Célia e SANTOS, Felipe. Divulgação de Informação. Cadernos do Mercado de Valores Mobiliários, n. ${ }^{\circ}$ 28, dez/2007, CMVM, Lisboa.

RODRIGUES, Sofia Nascimento Rodrigues, A Protecção dos Investidores em Valores Mobiliários, Coimbra: Almedina, 2001, p. 26.

ROMANO, Alberto Antonio. Princípios Rectores Del Mercado de Capitales (Lo Elemental para su Eficiência). In: VII Congreso Argentino de Derecho Societario y III Congresso Iberoamericano de Derecho Societario y de la Empresa. La Sociedad Comercial ante El tercer milênio, Buenos Aires.

SANCTIS, Fausto Martin de. Punibilidade no Sistema Financeiro Nacional: Tipos penais que tutelam o sistema financeiro nacional, incluindo o mercado de capitais. Campinas-SP: Millennium, 2003.

SILVA, José Afonso da. Curso de Direito Constitucional Positivo. $24^{\mathrm{a}}$ ed. São Paulo: Malheiros, 2005, 925p. 
SZTAJN, Rachel. Regulação e o Mercado de Valores Mobiliários. Revista de Direito Mercantil, Industrial, Econômico e Financeiro. São Paulo: Malheiros Editores, n. 135, jul-set/2004.

TORTIMA, José Carlos. Crimes Contra o Sistema Financeiro Nacional: Uma contribuição ao Estudo da Lei no 7.492/86. Rio de Janeiro: Lumen Iuris, 2002.

WALD, Alexandre de M. Uso de Prática Não-Eqüitativa. Inexistência: Memorial apresentado ao Conselho de Recursos do Sistema Financeiro Nacional. Revista de Direito Bancário, do Mercado de Capitais e da Arbitragem. São Paulo: Revista dos Tribunais, nº 9, jul set/2000. 